\title{
31. INHERITANCE AND NEOFORMATIONS IN THE SEDIMENTS OF THE CELEBES AND SULU BASINS (LEG 124) ${ }^{1}$
}

\author{
Elisabeth Nicot $^{2}$ and Alain Desprairies ${ }^{3}$
}

\begin{abstract}
From X-ray mineralogical studies and chemical analyses of the whole rocks and the fine fractions $(<2 \mu \mathrm{m})$ of ten to fifteen samples at each site of ODP Leg 124, two major sources were identified in the sedimentary components of the Celebes and Sulu basins: (1) a terrestrial and continental contribution; (2) a volcanic influx that gives way to well-defined volcanic units or to a dilute contamination, consisting of coarse-grained minerals (plagioclase, pyroxene, olivine, spinel) or a smectitic-rich fraction produced by the alteration of volcanic glasses and ashes.

The continental signature increases the amount of quartz in the rocks and the phyllitic association is complex: micas, kaolinite, disordered interstratified clay-minerals. The chemical compositions of the bulk rocks and the fractions $<2 \mu \mathrm{m}$ are more potassic and aluminum-rich. The volcanic imprint depends on the grain-size and chemical properties of the components. $\mathrm{Ca} / \mathrm{Na}$ contents highly variable compared to the $\mathrm{K}$ content of the bulk composition are due to the presence of coarse-grained volcanic plagioclase. The fractions $<2 \mu \mathrm{m}$ are more magnesian than in the continental regime.

The diagenesis is revealed by the crystallization of zeolites, the fixation of magnesium into the smectites that depletes the pore fluids in this element. Smectitization of the disordered interstratified clay minerals enriches the alkalinity of the pore fluids. Some deep formations of the Sulu Basin are affected by a thermal event, but no thermal event was recognized in the Celebes Basin.
\end{abstract}

\section{INTRODUCTION}

In the Celebes and Sulu Seas of Southeast Asia, LEG 124 drilling penetrated thick detrital and hemipelagic sequences, interbedded at different depths, with volcanic materials. The sedimentary sequences are not very thick. In the Sulu Sea, at Site 768, a volcanic sequence of basaltic flows, dolerites, and diabases was penetrated at $1046.65 \mathrm{mbsf}$. In the Celebes Sea a basaltic layer was encountered at $786 \mathrm{mbsf}$ at Site 767 . The oldest sediments are of Eocene age.

The oceanic crust of the Sulu Basin (Site 768) is relatively thin, $5.8 \mathrm{~km}$ according to refraction data (Murauchi et al., $1973)$, and heat-flow values are high $\left(110-180 \mathrm{~mW} / \mathrm{m}^{2}\right.$; Sclater et al., 1976; Kudrass et al., 1986; Hinz and Block, 1990), suggesting a young crust. The initiation time of basin formation and the variations of the heat-flow gradient with time are not well established.

This study focuses on the detrital sediments. The purpose is to evaluate, through the mineralogy and the chemistry of the bulk-rock and the fractions $<2 \mu \mathrm{m}$, the relative contributions of the terrestrial and volcanic influxes into the sedimentary basins, to follow the diagenetic evolution downhole by examining the interactions between the minerals and the pore fluids, and to evaluate whether heat flow influences the diagenesis.

\section{LITHOSTRATIGRAPHY}

At Site 767 (Fig. 1, Table 1A), the stratigraphic section begins with brown to reddish brown pelagic claystones (Unit IV), of Eocene and Oligocene age. Unit III of Miocene age

\footnotetext{
${ }^{1}$ Silver, E. A., Rangin, C., von Breymann, M. T., et al., 1991. Proc. ODP Sci. Results, 124: College Station, TX (Ocean Drilling Program).

2 E.N.S., Départment de Géologie, 24 rue Lhomond, F-75005 Paris, France.

${ }^{3}$ Université de Paris Sud, Laboratoire de Géochimie des Roches sédimentaires, Bât. 504, F-95405 Orsay, France.
}

consists of dark-green hemipelagic claystones. Subdivisions in Units IIIA, IIIB, and IIIC are based on the amount of claystones to silty claystones turbidites, quartz siltstones, and sandstones, clayey silt/siltstone and minor carbonate siltstone turbidites. Unit II, of late Miocene to Pleistocene age, consists of volcanogenic clayey silt/siltstones with interbedded carbonate turbidites. Unit IIA differs from Unit IIB by the presence of rare interbeds of volcanic ash. Unit I consists of volcanogenic clayey silt with rare ash interbeds.

At Site 768, the detrital sediments (Fig. 1, Table 1B) rest on a thick volcanic sequence (Unit V). The deepest sediments are dark-brown claystones (Unit V) interbedded with greenish gray tuff of early Miocene age. Unit IV, above, is a thick sequence of pyroclastic material, coarse lapilli, and tuffs. Unit III begins with red-brown claystones followed by normally graded beds of sandstones, siltstones, and claystones. Unit II of Miocene age is a thick sequence of interbedded claystones; silty claystones, clayey siltstones, and some sandstones. Minor lithologies include carbonate turbidite and ash layers. Unit I consists of pelagic-foraminifer-nannofossil marls, interbedded with calcareous turbidites.

At Site 769 (Fig. 1, Table IB), samples were collected from Unit II, subdivided in Unit IIB, a sequence of thin gray-brown to brown, massive bioturbated claystones of Miocene age, and from Unit IIA, late Miocene to Pliocene age, consisting of olive-gray, bioturbated or massive hemipelagic claystones. Unit I consists of pelagic foraminifer-nannofossil marls.

The main difference between the three stratigraphic sections is the frequency of well-defined volcanic beds interbedded in the detrital formations at Site 768 (Sulu Sea). At Site 767 (Celebes Sea), the volcanic contribution is diffuse and more abundant at the top of the stratigraphic sequence.

\section{METHODOLOGY AND ANALYTICAL PROCEDURES}

The mineralogical determinations were conducted by $\mathrm{X}$-ray diffraction methods (XRD) on bulk sediments and 

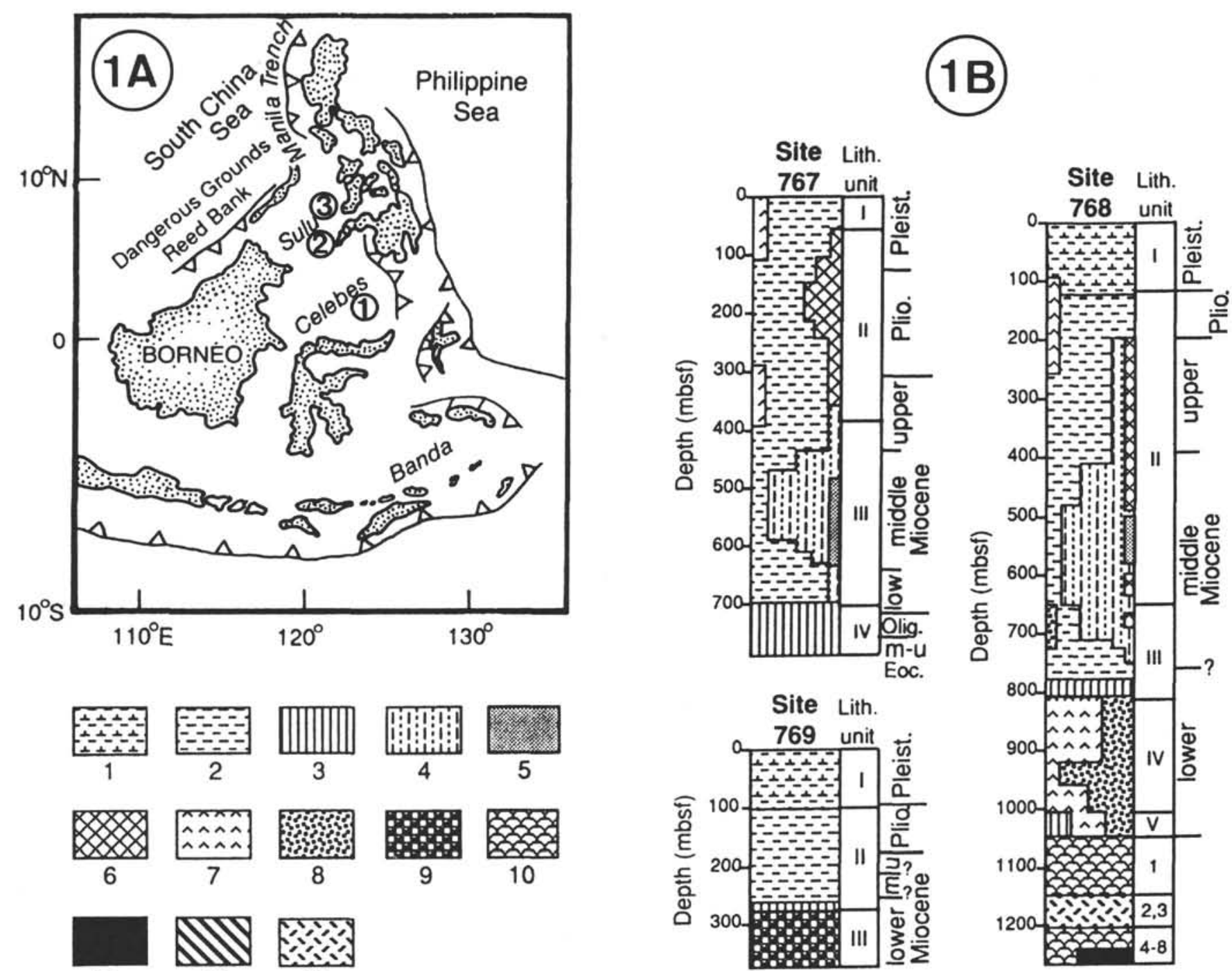

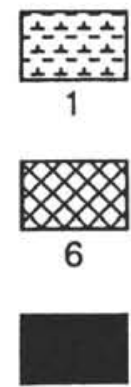

11

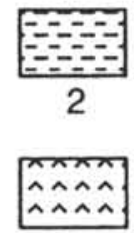

7

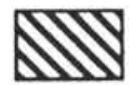

12

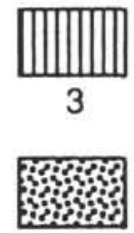

8

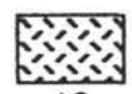

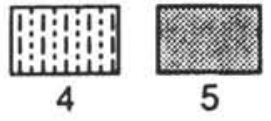

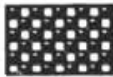

9

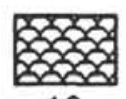

10

13

Figure 1. Schematic map and stratigraphic log of ODP Leg 124 (modified from figures 1 and 3, pp. 416-417, in Rangin, Silver, von Breymann, et al., 1990). 1A. Location of drilled sites. 1: Site 767; 2: Site 768; 3: Site 769. IB. Lithologic columns for Sites 767, 768, and 769. Symbols are (1) nanno- or nanno-foraminiferal marl; (2) hemipelagic sediments including clay/silt(stone); (3) pelagic brown claystone; (4) terrigenous turbidites; (5) quartz siltstone to sandstone; (6) graded carbonate turbidites; (7) fine ash/tuff; (8) pumiceous, rhyolitic to dacitic coarse tuff and lapillistone; (9) andesitic to basaltic coarse tuff and lapillistone; (10) pillow-basalt; (11) basalt sheet flow; (12) brecciated massive basalt; (13) diabase sill.

oriented clay-size fractions (automatic DACOMP/ IBM PC equipment, Philips generator, Siemens detector; Instrumental conditions: $30 \mathrm{kV}, 40 \mathrm{~mA}$; divergence slits $=1^{\circ}$, receiving slits $=0.1 \mathrm{~mm}$, scatters slits: $1^{\circ}, \mathrm{Cu} \mathrm{K} \alpha$ radiation with a Ni filter; a few samples were examined with Co $\mathrm{K} \alpha$ radiation).

The X-ray diffraction data are reported as the mineral percent relative to the sum of all the minerals. Peak counts were used without background correction. Minor phases sometimes noted in the XRD scans are not included.

The clay-size fraction ( $2 \mu \mathrm{m}$ ) was separated by ultrasonic desagregation in distilled water and by centrifugation and the fine fraction $(<35 \mu \mathrm{m})$ was obtained by repeated decantation from an aqueous suspension. Oriented samples were separated by filtration. The coarse-grained fraction ( $50 \mu \mathrm{m}-250$ $\mu \mathrm{m})$ was sieved and the grains were mounted in epoxy to be observed under the microscope.
The chemical analyses were performed on hand-crushed rocks and on the clay fractions using a scanning electron microscope (SEM) fitted with an energy dispersive spectrometer (SEM Phillips 505 with Link system). Scanning areas up to $100 \mathrm{~mm}^{2}$ were analyzed under $15 \mathrm{kV}$ with acquisition time of $120 \mathrm{~s}$. The relative errors are less than $3 \%$ for elements with concentrations between 5 and $10 \%$, and $20 \%$ for elemental concentrations $<5 \%$. The detection limit is $0.1 \%$. Weight deficits, due to water content, organic matter, and porous structure of the preparations, were variable from sample to sample. For comparison, all the analyses were recalculated to $100 \%$ oxide weight.

\section{MINERALOGICAL DESCRIPTION}

The brown claystones represent the marine pelagic sedimentation in all the basins, before the major geodynamic 
Table 1. References, depth, stratigraphy, and lithology of samples from Leg 124.

\begin{tabular}{|c|c|c|c|c|c|}
\hline $\begin{array}{l}\text { Core, section, } \\
\text { Interval }(\mathrm{cm})(\mathrm{m} .)\end{array}$ & Depth & Unit & Age & Color & Lithology \\
\hline \multicolumn{6}{|l|}{ Site 767 (Celebes Sea) } \\
\hline B-6H-1, 20-25 & 47.2 & I & Pleistocene & gray & Volcanogenic clayey silt \\
\hline B-10H-5, 95-97 & 86.9 & IIA & Pleistocene & dark gray & Volcanogenic clayey silt \\
\hline B- $22 \mathrm{X}-1,18-23$ & 193.7 & IIB & Pliocene & light gray & Volcanogenic clayey silt, carbonate turbidite \\
\hline B-35X-1, 69-71 & 320.1 & IIC & late Miocene & gray & Volcanogenic silty claystone \\
\hline B- $40 X-3,134-146$ & 372.5 & IIC & late Miocene & dark gray & Claystone \\
\hline B- $50 X-3,24-28$ & 467.3 & IIIA & middle Miocene & gray & Hemipelagic claystone, minor carbonate turbidite \\
\hline B- $54 \mathrm{X}-3,80-82$ & 506.3 & IIIB & middle Miocene & dark gray & Silty, sandstone turbidite \\
\hline B- $60 \times-2,100-103$ & 561.3 & IIIB & middle Miocene & gray & Turbidite claystone \\
\hline B-70X-5, 79-81 & 662.8 & IIIC & Miocene & light dark gray & Hemipelagic dark green claystone \\
\hline B-74X-6, 61- 63 & 707.2 & N & Miocene & light pinkish brown & Hemipelagic claystone \\
\hline B-75X-1, 127-129 & 705.5 & $\mathbf{N}$ & early Miocene & ed & Claystone \\
\hline B- $75 X-4,85-87$ & 709.5 & N & early Miocene & light brown & Claystone \\
\hline B-76X-4, 72-74 & 718.7 & N & early Miocene & ed & Claystone \\
\hline B-78X-1, 71-73 & 733.6 & N & late Miocene & light pink, and brown & Claystone \\
\hline B-78X-CC, $10-13$ & 734 & N & early Miocene & red to brown red & Claystone with manganese micronodules \\
\hline C- $6 \mathrm{R}-1,15-17$ & 726.3 & N & late Oligocene & brown to reddish brown & Claystone with manganese micronodules \\
\hline C-6R-1, 99-101 & 727.2 & N & late Oligocene & brown & Claystone and clayey tuff \\
\hline C- $-\mathrm{R}-3,46-48$ & 729.7 & N & late Oligocene & light brown & Claystone, clayey tuff, felsdpathique claystone \\
\hline C- $7 \mathrm{R}-2,67-70$ & 737.9 & $\mathbf{N}$ & late Oligocene & gray and light pinkish brown & Sandy claystone \\
\hline C-7R-CC, $6-8$ & 738.2 & N & early Oligocene & brown red & Claystone with manganese micronodules \\
\hline C- $8 \mathrm{R}-1,34-36$ & 772.7 & N & early Oligocene & dark and reddish brown & Claystone \\
\hline C-8R-1, 67-71 & 773.07 & N & early Oligocene & dark and reddish brown & Claystone \\
\hline C-8R-1, 73-75 & 773.13 & N & early Oligocene & pinkish white and brown & Claystone \\
\hline C-8R-1, 94-96 & 773.4 & N & early Oligocene & red brown & Claystone \\
\hline C- $9 \mathrm{R}-2,88-93$ & 755.4 & N & early Oligocene & white & Claystone with silstones and porcellanite \\
\hline
\end{tabular}

evolution. For that reason, they are described separately from the other detrital sediments. Some volcanic layers, sampled at Site 768 , are briefly described. In the other samples, the welldefined volcanic layers were not analyzed.

\section{Detrital Formations}

This section describes the detrital formations, such as hemipelagic clay (HMP), interbedded claystone/siltstones (ICS), turbidites (TB), and volcanogenic claystones/siltstones (VCS). The foraminifer-nannofossil marls of Pleistocene age (Unit I) from Sites 767 and 769 are not described.

\section{Bulk-Rock Mineralogical Composition}

\section{Site 767 (Celebes Sea)}

The volcanogenic claystones (Unit I and II) are characterized by an abundance of quartz and feldspars and the scarcity of the clay minerals and kaolinite (Table 2, Figs. 2A, 2B). Phillipsite occurs in some samples enriched in clay minerals. The decreasing amount of feldspar downward is striking (Table 2), but apparently is not correlated with the amount of clay minerals and kaolinite. Below, in the hemipelagic formation (Unit III), the feldspars are less common. The clay mineral and quartz are the major components (Figs. 2C, 2D). The clay minerals content increases at the bottom of the sequence. Quartz abundance increases strongly in the Unit IIIB. Chlorite and micas occur irregularly at the top of the formation.

Heavy minerals (pyroxenes, olivine, brown, or green amphibole, biotite, and plagioclases) are present in the coarsegrained fraction of many sediments. Their shapes are sometimes rounded as in turbidites (Core 124-767B-54X-3, 80-82, or $-60 \mathrm{X}-2,100-103)$. Some vitric pumice is also observed in volcanogenic clayey silt (Unit II: Core 124-767B-10H-5, 95-97).

The coarse-grained fraction is also rich in a green glauconite-like mineral. The mineral appears as patches or overgrowths on brown elliptical fine-grained elements of unknown origin, or as individual grains.

\section{Site 768 (Sulu Sea)}

The mineralogical composition of the interbedded claystones and siltstones (Unit II) is dominated by a constant association of feldspar, quartz, micas, and kaolinite (Fig. 3,
Table 2). Chlorite is common. The proportion of clay minerals is very low at the top of the sequence and a strong increase in quartz occurs at about $400 \mathrm{mbsf}$.

\section{Site 769 (Cagayan Block)}

The mineralogical association of the hemipelagic sediments (Unit IIA) is similar to that of the detrital sequence at Site 768 and different from the mineralogical association of the hemipelagic sediments at Site 767 (Table 2).

\section{The Fine-Fraction $(<2 \mu \mathrm{m})$}

The mineralogical associations of the fine fractions are presented in Table 3. Mica/illite, and kaolinite are abundant. Chlorite is common in the Sulu sediments, but never abundant.

\section{Significance of the 17-A Peak}

The glycolated X-ray profiles exhibit a strong peak at about $17 \AA$. The valley of the first peak at low angle is usually high, especially in the turbidite or the interbedded siltstones/claystones (Figs. 4 and 5). D-values vary from 17.2- up to 17.5 - $\AA$ values, and are higher than in the brown claystones and the volcanic material.

This peak is not from a pure-disordered illite/smectite clay mineral. Studies of natural samples and simulations of X-ray profiles on computer (Reynolds et al., 1970) have demonstrated a coherent variation, first in the increasing height of the valley/peak at $17 \AA$ with the migration of the $(001)_{17}$ peaks toward higher angles, and second in the convergent migration of the $(001)_{17}$ and $(001)_{10}$ peaks. This never occurs in the studied samples (Table 4). At Site 767 (Celebes Sea), both peaks migrate in the same direction. The higher saddle/peak ratios of the $17-\AA$ peak are associated with the higher d-values. The positions and valley/peak ratios are independent of the depth. At Site 768 (Sulu Sea), the variations in the peak positions of the $17-\AA$, $8.5-\AA$, and $10-\AA$ peaks and the valley/ peak ratio are particularly erratic.

The 17- $\AA$ peak appears as an envelope of elementary peaks corresponding to different individual clay minerals in various proportions: smectite, ordered mixed-layer as the d-values rise up to $17.7 \AA$, and random mixed-layer illite/smectite. The disordered mixed-layer illite/smectite clay minerals are, how- 
Table 1 (continued).

\begin{tabular}{|c|c|c|c|c|c|}
\hline $\begin{array}{l}\text { Core, section, } \\
\text { Interval }(\mathrm{cm})(\mathrm{m} .)\end{array}$ & Depth & Unit & Age & Color & Lithology \\
\hline \multicolumn{6}{|l|}{ Site 768 (Sulu Sea) } \\
\hline $\begin{array}{l}\text { B-18H-1, 100-105 } \\
\text { B-28X-1, 108-113 } \\
\text { B-33X-2, 130-134 } \\
\text { C-1R-3, 113-115 } \\
\text { C-6R-2, 20-23 } \\
\text { C-11R-5, 15-17 } \\
\text { C-18R-4, 62-66 } \\
\text { C-23R-1, 92-94 } \\
\text { C-29R-4, 13-16 } \\
\text { C-39R-4, 24-27 } \\
\text { C-48R-5, 115-117 } \\
\text { C-49R-1, 52-54 } \\
\text { C-50R-1, 2-4 } \\
\text { C-50R-3, 55-57 }\end{array}$ & $\begin{array}{l}157 \\
2397 \\
289.7 \\
357.3 \\
403.1 \\
455.7 \\
522.3 \\
566.4 \\
628.1 \\
724.9 \\
813.7 \\
816 \\
825.5 \\
829\end{array}$ & $\begin{array}{l}\text { II } \\
\text { II } \\
\text { II } \\
\text { II } \\
\text { II } \\
\text { II } \\
\text { II } \\
\text { II } \\
\text { II } \\
\text { III } \\
\text { N } \\
\text { N } \\
\text { N } \\
\text { N }\end{array}$ & $\begin{array}{l}\text { Pliocene } \\
\text { late Miocene } \\
\text { late Miocene } \\
\text { late Miocene } \\
\text { middle Miocene } \\
\text { middle Miocene } \\
\text { middle Miocene } \\
\text { Miocene } \\
\text { Miocene } \\
\text { Miocene } \\
\text { early, middle Miocene } \\
\text { early, middle Miocene } \\
\text { early, middle Miocene } \\
\text { early, middle Miocene }\end{array}$ & $\begin{array}{l}\text { dark green } \\
\text { light greenish gray } \\
\text { dark green } \\
\text { light greenish gray } \\
\text { brown gray } \\
\text { light gray } \\
\text { light greenish gray } \\
\text { light green } \\
\text { light brown gray } \\
\text { light brown gray } \\
\text { dark green } \\
\text { blue green } \\
\text { brown red } \\
\text { blue green }\end{array}$ & $\begin{array}{l}\text { Clay } \\
\text { Interbedded clay, silt, sand. Mostly turbidites } \\
\text { Interbedded clay, silt, sand. Mostly turbidites } \\
\text { Interbedded claystone, silty claystone } \\
\text { Interbedded claystone, silty claystone } \\
\text { Interbedded claystone silty claystone, silstone } \\
\text { Interbedded claystone silty claystone, silstone } \\
\text { Interbedded claystone, clayey claystone } \\
\text { Interbedded claystone, clayey siltstone } \\
\text { Coarse volcanic ash tuff } \\
\text { Pyroclastic material, coarse lapilli and tuff } \\
\text { Claystone with fine tuff } \\
\text { Fine tuff turbidite } \\
\text { Pyroclastic material }\end{array}$ \\
\hline \multicolumn{6}{|c|}{ Site 769 (Cagayan block) } \\
\hline $\begin{array}{l}\text { B-16H-4, 31-33 } \\
\text { B-20H-6, 31-35 } \\
\text { B-30X-CC, 6-8 } \\
\text { B-30X-CC, 23-25 } \\
\text { C-2R-5, 133-136 } \\
\end{array}$ & $\begin{array}{l}142.9 \\
181.1 \\
278.6 \\
278.7 \\
278.1 \\
\end{array}$ & $\begin{array}{l}\text { IIA } \\
\text { IIA } \\
\text { IIB } \\
\text { IIB } \\
\text { III }\end{array}$ & $\begin{array}{l}\text { Pliocene } \\
\text { Pliocene } \\
\text { early to late Miocene } \\
\text { early to late Miocene } \\
\text { early to late Miocene }\end{array}$ & $\begin{array}{l}\text { greenish gray } \\
\text { greenish gray } \\
\text { light pinkish brown } \\
\text { light pinkish brown } \\
\text { pinkish brown }\end{array}$ & $\begin{array}{l}\text { Hemipelagic clay } \\
\text { Hemipelagic clay } \\
\text { Silty clay } \\
\text { Silty clay } \\
\text { Clay }\end{array}$ \\
\hline
\end{tabular}

ever, an important component of the associated clay minerals as indicated by a projection of the peak angular distances along the disordered illite/smectite curve in Fig. 6 (Inoue et al., 1983; Srodon et al., 1984).

For such mixtures, any simulation of a diffraction profile is inadequate. A broad comparison with pure disordered interstratified minerals of the illite/smectite series indicates that the percentage of illite in the mixed-layer minerals, in fact an "apparent illite content", varies between $20 \%$ to $50 \%$ (Table $3)$, (Reynolds and Hower, 1970). The proportion of illite layer in the disordered mixed-layer clay minerals increases linearly with the amount of micas and kaolinite on the diffraction profiles (Fig. 7). Although the complex composition of the clay fraction cannot be determined in detail, the apparent illite content indicates some contrast between the two basins. In the Celebes Sea (Site 767), the fraction mixture $<2 \mu \mathrm{m}$ is, on average, more rich in smectite layers than the Sulu clay fractions, in agreement with the lower abundance of the micas and kaolinite. At Site 769 (Cagayan block), the fine fraction $(<2 \mu \mathrm{m})$ of the hemipelagic sediments is comparable to the fine fraction of the detrital sequence of the Sulu Sea, but not to the fine hemipelagic sediments of the Celebes sea.

\section{Ordered Mixed-layer Clay Minerals}

In half of the X-ray profiles of the fractions $<2 \mu \mathrm{m}$, some more weak and broad peaks were detected at about $31,25-27,15$, and 13 $\AA$. Such peak positions are also observed in a pyroclastic volcanic layer (Sample 124-768C-50R-3, 55-57; see below). They signal the presence of ordered interstratified clay minerals, either trioctahedral minerals $(14+17)$, or dioctahedral $(10+17)$.

\section{Conclusion}

The bulk rock mineralogy in the three sites and the different lithologies are compared in Table 2.

1. The volcanogenic clayey siltstones (Unit I and II, Site 767) are distinct from all the other sediments by their high feldspar content.

2. The hemipelagic sediments at Site 767 (Celebes Sea) are more clay-rich than the interbedded claystones/siltstones from Site 768 or the hemipelagic sediments at Site 769 (Cagayan block). In the latter, micas and kaolinite are more abundant and the chlorite is a discrete but common phase. On average, the "apparent illite content" in the clay-size fraction is lower in the hemipelagic sediments at Site 767 (Celebes Sea). All these characters indicate that the detrital influx in the Celebes Sea (Site 767) consists of a finer-grained or a more degraded material than in the Sulu Sea (Site 768) and Cagayan block (Site 769).

3. In all sites, at the top of the sedimentary sequences, the sediments are poor in clay minerals (Units 1 and II), whatever the lithologies. This property may indicate either a change in the grain size of the detrital material or some clay neoformation downward in the sequences.

4. Pure smectite, if present, is undetectable in the X-ray profiles. The continentality index, defined as $\log (\mathrm{Sm}+\mathrm{I}+\mathrm{Chl} /$ $\mathrm{Sm})$ and used to oppose the detrital influx $(\mathrm{I}+\mathrm{Chl})$ to the volcanic influence $(\mathrm{Sm})$ should be used with caution.

\section{Brown Claystones}

Pelagic brown claystones are represented in the three sites at different depths (Table 1 and Fig. 1). At Site 768, the brown claystones constitute two distinct sequences that bracket a thick volcanic unit. As mentioned in the stratigraphic presentation, white or gray or greenish layers are interbedded in the brown, dark-brown, or red-brown claystones.

The mineralogical composition of the whole-rock and fine fractions $(<35 \mu \mathrm{m}$ and $<2 \mu \mathrm{m})$ as determined by $\mathrm{X}$-ray diffraction, are presented respectively in Tables 2 and 3.

\section{Whole-rock Mineralogy}

The brown claystones are composed of smectite-rich clay and various amounts of quartz, feldspars, micas, and traces of disordered interstratified minerals (Fig. 8A). In the Celebes sediments, most of the brown claystones are relatively rich in quartz. A $10-\AA$ phase is common, and feldspars are rare. In the Sulu brown claystones, feldspar is a prominent phase. Quartz, kaolinite, and micas are rare. In the Cagayan block, the brown claystones are rich in feldspars as the Sulu claystones. They resemble also the Celebes Sea claystones by the other mineralogical characters. The Cagayan block appears as a transitional area between the two basins.

The profiles of white or light-gray interbeds are characterized by a strong peak at about $14-15 \AA$ (Fig. 8C). The micas are usually absent or rare, and quartz and feldspars are present in moderate proportion. 
Table 2. Relative XRD peak intensities of minerals detected in detrital sediments from Leg 124.

\begin{tabular}{|c|c|c|c|c|c|c|c|c|c|c|c|}
\hline \multirow[t]{2}{*}{ Unit } & \multirow{2}{*}{$\begin{array}{l}\text { Core, section } \\
\text { interval (cm) }\end{array}$} & \multirow[t]{2}{*}{ Lith } & \multirow[b]{2}{*}{ Chl } & \multicolumn{4}{|c|}{ Whole-rock mineralogy } & \multirow[b]{2}{*}{$\mathrm{K}$} & \multirow[b]{2}{*}{$Q$} & \multirow[b]{2}{*}{$\mathrm{F}$} & \multirow[b]{2}{*}{$\mathrm{Cc}$} \\
\hline & & & & a & M & Clp & $\mathrm{Ph}$ & & & & \\
\hline \multicolumn{12}{|c|}{ Site 767 (Celebes Sea) } \\
\hline I & B-6H-1, 20-25 & ves & & & & & & & 23 & $\pi$ & \\
\hline Ila & B- $10 \mathrm{H}-5,95-97$ & VCS & & & 28 & & & & & 72 & \\
\hline IIb & B- $22 \mathrm{X}-1,18-23$ & VCS & & & & & & 23 & 19 & 58 & \\
\hline II & B-35X-1, 69-71 & VCS & & 14 & & & 36 & & 14 & 36 & \\
\hline Ilc & B- $40 \times-3,134-146$ & $\mathrm{C}$ & & 33 & 15 & & II & 13 & 13 & 15 & \\
\hline IIA & B- $50 X-3,24-28$ & HMP & 20 & 18 & 9 & & & 14 & 13 & 14 & 12 \\
\hline IIIB & B- $54 \mathrm{X}-3,80-82$ & $\mathrm{~TB}$ & & 21 & 18 & & & & 61 & & \\
\hline $\mathrm{IIIB}$ & B-60X-2, $100-103$ & $\mathrm{~TB}$ & & 24 & & & & 14 & 45 & 16 & \\
\hline IIIC & B-70X-5, 79-81 & HMP & & 34 & & & & 21 & 21 & 24 & \\
\hline IIC & B- $74 X-6,61-63$ & HMP & 38 & 20 & & & 12 & 19 & 11 & & \\
\hline N & B- $75 X-1,127-129$ & PC & 16 & 17 & 18 & & & 16 & 22 & 13 & \\
\hline IIIC & B- $75 X-4,85-87$ & PC & & 29 & $\begin{array}{l}10 \\
18\end{array}$ & & & 10 & 25 & 18 & \\
\hline $\mathrm{N}$ & B- $76 \times-4,72-74$ & PC & & 52 & B & & & & 20 & 14 & \\
\hline $\mathrm{N}$ & B-78X-1, 71-73 & PC & & 66 & & & & & 18 & 16 & \\
\hline N & B-78X-CC, $10-13$ & PC & & 38 & 27 & & & 15 & 21 & & \\
\hline N & C- $6 \mathrm{R}-1,15-17$ & PC & & 57 & 10 & & & & 21 & 12 & \\
\hline $\mathrm{N}$ & C-6R-1,99-101 & PC & & 42 & 15 & & & & 25 & 18 & \\
\hline $\mathrm{N}$ & C- $6 \mathrm{R}-3,46-48$ & PC & & 54 & iI & & & & 15 & 19 & \\
\hline $\mathrm{N}$ & C- $7 \mathrm{R}-2,67-70$ & $\mathrm{PCr}$ & & 36 & 16 & & & & 26 & 11 & \\
\hline $\mathrm{N}$ & $C-7 R-2,67-70$ & $\mathrm{PCw}$ & & 60 & & & & 12 & 28 & & \\
\hline $\mathrm{N}$ & C-7R-CC, $6-8$ & PC & & 64 & & & & & 15 & 21 & \\
\hline N & C- $8 \mathrm{R}-1,34-36$ & PC & & 42 & 14 & 12 & & & 16 & 16 & \\
\hline $\mathrm{N}$ & C-8R-1, $73-75$ & PC & & 70 & & & & & 17 & 12 & \\
\hline N & C-8R-1, 67-71 & PC & & 39 & 13 & 18 & & & 14 & 17 & \\
\hline $\mathrm{N}$ & C-8R-1, $94-96$ & PC & & 54 & 15 & & & & 18 & 13 & \\
\hline $\mathrm{N}$ & C-9R-2, 88-93 & $\mathrm{PCw}$ & & 100 & & & & & & & \\
\hline \multicolumn{12}{|c|}{ Site 768 (Sulu Sea) } \\
\hline 1 & B-18H-1, $100-105$ & C & 18 & & 19 & & & 24 & 19 & 20 & \\
\hline II & B- $28 \mathrm{X}-1,108-113$ & ICS & 14 & & 17 & & & 16 & 32 & xo & \\
\hline II & B- $33 \mathrm{X}-2,130-134$ & ICS & 18 & & 20 & & & 21 & 23 & 18 & \\
\hline II & C-1R-3, 113-115 & ICS & 7 & & 11 & & & 16 & 45 & 21 & \\
\hline II & C- $6 \mathrm{R}-2,20-23$ & ICS & 4 & & 6 & & & 8 & 63 & $x$ & \\
\hline III & C-11R-5, 15-17 & ICS & 5 & & 10 & & & 14 & 51 & 21 & \\
\hline II & C- $18 R-4,62-66$ & ICS & 14 & 15 & 23 & & & 23 & 14 & 11 & \\
\hline II & C- $23 \mathrm{R}-1,92-94$ & ICS & 16 & 15 & 18 & & & 20 & 18 & 13 & \\
\hline III & C- $29 \mathrm{R}-4,13-16$ & ICS & 6 & 8 & 10 & & & 14 & 43 & 19 & \\
\hline III & C- $39 R-4,24-27$ & VT & & 50 & & 19 & & & 12 & 19 & \\
\hline $\mathrm{N}$ & C- $49 \mathrm{R}-1,52-5$ & CVT & 15 & & 12 & & & & 14 & 41 & \\
\hline $\mathrm{N}$ & C-50R-3, 55-57 & VP & 6 & & 19 & 21 & & & 14 & 41 & \\
\hline $\mathrm{N}$ & C-60R-1, 2-4 & VT & & 41 & 18 & & & 12 & 12 & 18 & \\
\hline \multicolumn{12}{|c|}{ Site 769 (Cagayan Block) } \\
\hline IIA & B- $16 \mathrm{H}-4,31-33$ & HMP & 16 & & 23 & & & 21 & 21 & 20 & \\
\hline IIA & B-20H-6, 31-35 & HMP & $\begin{array}{l}10 \\
19\end{array}$ & 18 & 18 & & & 18 & 15 & 12 & \\
\hline IIB & B-30X-CC, 6-8 & PC & & & & & 19 & & 15 & 39 & \\
\hline IIIB & B-30X-CC, $23-25$ & PC & & 55 & & & & & 20 & 25 & \\
\hline IIA & C- $2 \mathrm{R}-5,133-136$ & PC & & 26 & 15 & & & 18 & 17 & 24 & \\
\hline
\end{tabular}

N.B.: Chl: Chlorite; Cl: Clay; M: Mica; Clp: Clinoptilolite; Ph: Phillipsite; K: Kaolinite; Qz: Quartz; F: Feldspath; Cc: Calcite.

Lith: Lithology, VCS : Volcanogenic silty claystone; C: Clay; HMP : hemipelagic claystone; TB : turbidite; PC: pelagic claystone; ICS : Interbedded claystone/siltstone; VT : volcanic tuff; CVT: calystone with fine tuff VP: volcanic pyroclastite.

r: red layer; w: white layer

Intermediate profiles between these two extremes are represented in Figure 8C.

Volcanogenic minerals are present in the brown to dark brown beds: in the Sample 124-767C-6R-1, 15-17 cm bed, spinel, olivine, and pyroxene were recognized in various amounts in the 200 - to $50-\mu \mathrm{m}$ fractions; in the Sample 124-767C-7R-CC, 6-8 cm, pyroxene and spinel are abundant only in the $80-\mu \mathrm{m}$ fraction. Clearly, coarse-grained volcanic material, either primary or reworked, was deposited in the basin. Those minerals are absent in the white or light-gray beds. No vitric constituents were found in them. Zeolites, phillipsite or clinoptilolite, appear only in two samples. Goethite is present in some profiles.

\section{Clay-size Fraction}

The clay-size fraction (Fig. 9) is always rich in smectite. The proportions of micas and kaolinite vary from one sample to another and the amount of disordered interstratified clay minerals is related to those variations: the higher the mica and kaolinite proportions, the higher the saddle/peak of the first 17 - $\AA$ peak. Zeolites are barely detectable in the fraction $<2$ $\mu \mathrm{m}$. The white or light-colored claystones (Fig. 9A) have a pure smectitic fraction.

\section{Conclusion}

The mineralogy of the brown claystones suggests several influences in the basins:

1. A coarse-grained detrital influx; quartz, micas, and the associated interstratified minerals are considered to be of detrital continental origin. This contribution is minor, but relatively constant all along the sequence.

2. A volcanogenic contribution of coarse-grained ferromagnesian minerals of terrestrial or submarine origin. 


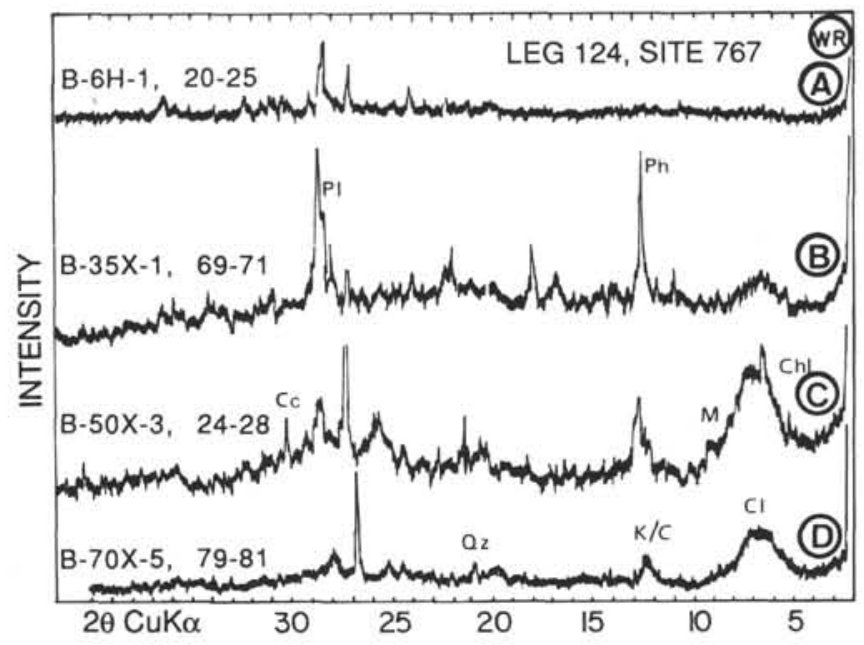

Figure 2. Whole-rock diffraction profiles of detrital sediments at Site 767, Leg 124. (Cc: calcite; Cl: clay; Chl: chlorite; K/C: kaolinite/ chlorite; M: mica; PI: plagioclase; Ph: phillipsite; Qz: quartz; WR: whole rock). Core sample numbers are at left.

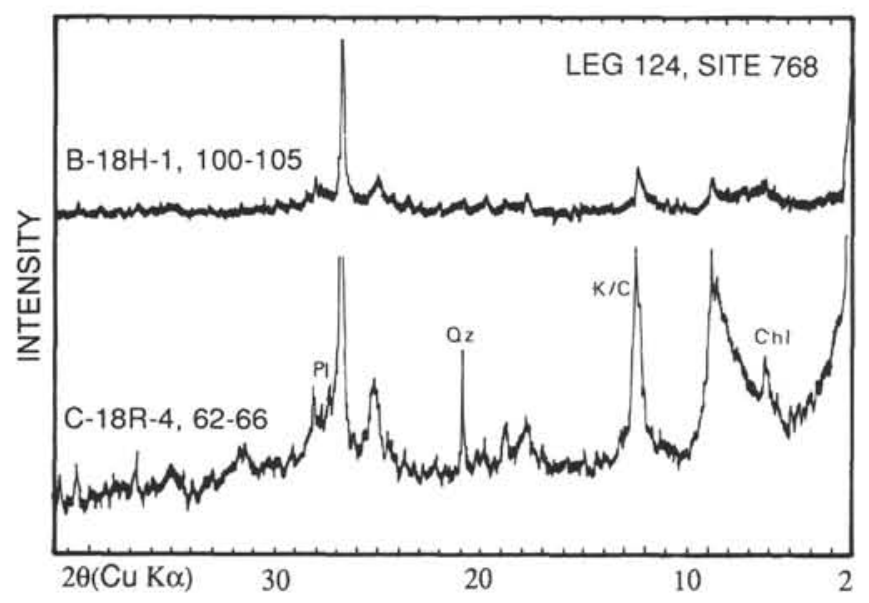

Figure 3. Whole-rock diffraction profiles of detrital sediments from Unit II at Site 768, Leg 124. (Chl: chlorite; K/C: kaolinite/chlorite; M: mica; Pl: plagioclase; Qz: quartz). Core sample numbers are at left.

3. A feldspar contribution, apparently independent of the continental influx, as no correlation exists with the amount of micas, quartz, or kaolinite.

4. A smectitic fraction. The high concentration of almost pure smectite in the whitish interbeds is probably an indicator of volcanogenic origin. In the brown beds, the smectite is also abundant, but is more often mixed with randomly interstratified clay minerals of detrital origin.

\section{Volcanic Beds}

Volcanic layers were sampled at Site 768 (Table 1B). The Unit III Sample 124-768C-39R-4, 24-27 cm, corresponds to a coarse tuff layer, interbedded into graded beds of Miocene sandstone, siltstone, and claystone. Very rich in clay (Fig. $10 \mathrm{~A})$, it also contains clinoptilolite as a major phase. The fine fraction is made of almost pure smectite, with a very low saddle/peak ratio of the $17-\AA$ peak (Fig. 11A).

Another fine tuff (Unit IV: Sample 124-768C-50R-1, 2-4 $\mathrm{cm})$, supposedly a turbiditic deposit, is enriched in mica and quartz (Fig. 11C). Disordered mixed-layer clay minerals are present in the clay fraction (Fig. 11B).

The Unit IV Sample 124-768C-50R-3, 55-57 cm, comes from a unit of pyroclastic, coarse lapilli, and tuff material, interfingered between two brown claystone units. This formation is indurated and most of the samples have a blue-green color (Shipboard scientific party, 1990).

The whole-rock diffraction profile (Fig. 10B) shows a strong decrease in clay minerals, and large amounts of clinoptilolite. Some micas and chlorite are also present (Table 2). The fraction $<2 \mu \mathrm{m}$ produces an unusual X-ray profile as compared to all the other samples (Fig. 12). This complex pattern is interpreted as a mixture of three phases: a $10-\AA$ phase, an ordered interstratified illite-smectite clay mineral, giving the $13-\AA(002)$ and the $8.4-\AA$ (003) peaks, and an ordered chlorite/smectite interstratified mineral $(14+17 \AA=$ $31 \AA$ ) with more smectite layers than chlorite layers.

These samples have a completely different clay mineral association, both neoformed, but incompatible in term of thermal stability.

\section{CHEMICAL COMPOSITIONS}

\section{Bulk-rock Chemistry}

The chemical analyses of the rocks (Table 5) must be corrected for sodium chloride. As seen in Figure 13, high sodium and chlorine contents were detected in the upper sediments of the different sites. Both elements decrease down in the wells, as do the porosity and water contents. These evolutions reflect the degree of compaction of the sediments. One sample in the Celebes sediments (Site 767) especially rich in $\mathrm{SO}_{3}$ and $\mathrm{FeO}$, is an exception.

\section{Bulk-rock Classification}

\section{Detrital Formations}

The calcium content (\%) of the sediments at Site 768 (Sulu Sea) is very low compared to Site 767 (Celebes Sea) and Site 769 (Cagayan Block) sediments (Table 5). As calcite was detected by X-ray diffraction in only one sample from Site 767 , the source of the calcium in the sediments at all sites should be silicate minerals.

Besides the first criteria of the calcium content, the chemical compositions of the various lithologies were classified on the basis of their iron content and less, on the magnesium and potassium contents (Table 6).

\section{Calcium-poor Sediments}

In the interbedded claystones/siltstones (ICS) from the Sulu Sea (Site 768, Unit II), the main trend is an increase in aluminum and potassium as silica decreases. These variations reflect the different proportions of mica, disordered interstratified clay minerals and quartz in the rocks. No relationships between the iron content and the other elements could be found.

The low-Ca turbidite from Site 767 (Unit IIIB, Ceiebes Sea) is particularly rich in iron and resembles closely some interbedded claystones/siltstones from Site 768 (Sulu Sea).

\section{Calcium-rich Sediments}

Among the calcic sediments, the hemipelagic sediments (HMP) are, on average, more aluminous (Table 6). Compared to the interbedded claystones/siltstones from Sites 768 (Unit II), they are more sodic and magnesian but less potassic and silicic.

The sandstones and turbiditic sediments (TB) of various units at Site 767 (Celebes Sea) are more silicic and less magnesian and aluminous than the hemipelagic sediments. 
Table 3. Relative XRD peak intensities of minerals detected in the clay size fractions of sediments from Leg 124.

\begin{tabular}{|c|c|c|c|c|c|c|c|c|c|c|}
\hline \multirow[t]{2}{*}{ Unit } & \multirow{2}{*}{$\begin{array}{l}\text { Core, section } \\
\text { interval }(\mathrm{cm})\end{array}$} & \multirow[t]{2}{*}{ Lith } & \multicolumn{8}{|c|}{ Fine fraction mineralogy } \\
\hline & & & $\mathrm{Chl}$ & $\mathrm{a}$ & $M$ & Clp & $\mathrm{K}$ & $\mathrm{F}$ & $\mathrm{Cc}$ & \%III \\
\hline \multicolumn{11}{|c|}{ Site 767 (Celebes Sea) } \\
\hline I & B-6H-1, 20-25 & VCS & 7 & 55 & 19 & & 11 & 8 & & 41 \\
\hline Ifa & B-10H-5, $95-97$ & VCS & & 99 & 22 & & 19 & & & 42 \\
\hline $\mathrm{IIb}$ & B- $22 X-1,18-23$ & VCS & & 73 & 15 & & 11 & & & 3 \\
\hline II & B-35X-1, 69-71 & VCS & & 90 & & & 10 & & & 25 \\
\hline IIc & B- $40 X-3,134-146$ & $\mathrm{C}$ & 5 & 87 & & & 7 & & & 26 \\
\hline IIA & B- $50 X-3,24-28$ & HMP & 6 & 55 & 14 & & 12 & 7 & 7 & 23 \\
\hline IIIB & B- 54 X- $3,80-82$ & $\mathrm{~TB}$ & 5 & 67 & 19 & & 9 & & & 30 \\
\hline IIIB & B- $60 \times-2,100-103$ & $\mathrm{~TB}$ & & 47 & 23 & & 14 & 9 & & 44 \\
\hline IIIC & B-70X-5, 79-81 & HMP & 6 & 73 & 12 & & 8 & & 6 & 26 \\
\hline N & B-75X-1, $127-129$ & PC & & $x$ & 16 & & B & & & 34 \\
\hline N & B- $78 X-C C, 10-13$ & $\mathrm{PC}$ & & 78 & 12 & & 5 & & 5 & 20 \\
\hline N & C- $6 \mathrm{R}-1,15-17$ & PC & & 90 & 7 & & 3 & & & 10 \\
\hline N & C- $6 \mathrm{R}-3,46-48$ & PC & & 97 & & & 3 & & & 5 \\
\hline N & C-7R-CC, $6-8$ & PC & & 100 & & & & & & 5 \\
\hline N & C- $8 \mathrm{R}-1,73-75$ & PC & & 98 & & & 2 & & & 5 \\
\hline $\mathrm{N}$ & C-8R-1, 67-71 & PC & & 86 & 9 & & & & 5 & 19 \\
\hline \multicolumn{11}{|c|}{ Site 768 (Sulu Sea) } \\
\hline I & B- $18 \mathrm{H}-1,100-105$ & $\mathrm{C}$ & 6 & 54 & 21 & & 13 & & 5 & \\
\hline II & B- $28 X-1,108-113$ & ICS & 9 & 64 & & & 12 & 10 & 6 & 42 \\
\hline II & B- $33 \mathrm{X}-2,130-134$ & ICS & 7 & 44 & 35 & & 13 & & & \\
\hline II & C-1R-3, 113-115 & ICS & 33 & & 44 & & 33 & & & \\
\hline II & C- $6 \mathrm{R}-2,20-23$ & ICS & 8 & 61 & 20 & & 11 & & & 37 \\
\hline II & C- $11 \mathrm{R}-5,15-17$ & ICS & 7 & 50 & 23 & & 11 & 8 & & 46 \\
\hline II & $C-18 R-4,62-66$ & ICS & 8 & 44 & 33 & & 15 & & & 56 \\
\hline II & C- $23 \mathrm{R}-1,92-94$ & ICS & 8 & 47 & 25 & & 13 & 8 & & 49 \\
\hline II & C- $29 \mathrm{R}-4,13-16$ & ICS & 9 & 37 & 38 & & 16 & & & \\
\hline III & C- $39 R-4,24-27$ & VT & & 91 & 5 & 4 & & & & 8 \\
\hline$N$ & C- 60 R-1, $2-4$ & VT & & 85 & 9 & 4 & 3 & & & 20 \\
\hline \multicolumn{11}{|c|}{ Site 769 (Cagayan Block) } \\
\hline ПIА & B-16H-4, 31-33 & HMP & 6 & 58 & 15 & & 14 & 6 & & 40 \\
\hline IIA & B- $20 \mathrm{H}-6,31-35$ & HMP & 0 & 60 & 23 & & 17 & & & 51 \\
\hline
\end{tabular}

The distinction between the two lithologies becomes difficult for claystone turbidites.

The volcanogenic clayey silts (VCS) and silty claystones (SC) constitute the most heterogeneous group. Rich in iron, they share with the pyroclastic material a high calcium content, except for the most silicic and potassium- rich beds, in which phillipsite is present. The lack of distinctive chemistry results from the mixed-nature of these sediments.

\section{Pelagic Sediments}

Variations in the bulk compositions of the brown claystones are as important as they are in the other detrital sediments (Table 7).

The more aluminous $(>21 \%)$ brown claystones are the less calcic $(<2 \%)$ and sodic $(<2 \%)$ sediments. The iron-rich $(>0 \%)$ brown claystones are subdivided in a manganiferous group less rich in potassium $(>3 \%)$ than the non-manganiferous group. The more sodic $(>3 \%)$ brown claystones are also the more magnesian sediments $(>5 \%)$. The less potassic $(<2 \%)$ brown claystones are all rich in calcium and relatively sodic. They are relatively poor in iron but rich in magnesium. Two samples, the more manganiferous, do not fall within any of the previous groups.

\section{$\mathrm{CaO} / \mathrm{Na}_{2} \mathrm{O} / \mathrm{K}_{2} \mathrm{O}$ Variations}

Considering all the data, three elements are particularly useful.

1. The calcium separates the sediment of Site 767 from the two others. $\mathrm{Ca}$ increases in the sediments contaminated by volcanic influx and, with the exception of one sample, it cannot be attributed to the presence of calcite.

2. The potassium is characteristic of the detrital sediments, interbedded claystones/siltstones, and hemipelagic sediments, and also of some brown claystones.

3. The sodium is usually lower in the sediments poor in calcium. The relative variations of these three elements are important because they compete in feldspars, zeolites, and clay minerals.

The interbedded claystones/siltstones of the Sulu Sea (Site 768 , Unit II) plot near the $\mathrm{K}_{2} \mathrm{O}$ pole and are subdivided in two groups (Fig. 14A). The first one with $\mathrm{K}_{2} \mathrm{O} / \mathrm{Na}_{2} \mathrm{O}$ ratio $>75 \%$ includes the sediments rich in detrital micas and kaolinite. The second one, more sodic in composition $\left(65<\mathrm{K}_{2} \mathrm{O} / \mathrm{Na}_{2} \mathrm{O}<\right.$ $75 \%$ ), corresponds to the more silicic sediments.

The $\mathrm{CaO} / \mathrm{Na}_{2} \mathrm{O} / \mathrm{K}_{2} \mathrm{O}$ variations are more extensive in the Celebes Sea sediments (Site 767, Fig. 14B). The hemipelagic sediments and the turbiditic siltstones and claystones are less potassic than the detrital sediments of the Sulu Sea. They are distributed along a line with a relatively constant $\mathrm{CaO} / \mathrm{Na}_{2} \mathrm{O}$ ratio. At one end, the line intersects the $\mathrm{K}_{2} \mathrm{O}$-rich area defined by the claystones/siltstones of the Sulu Sea (Site 768). Along the line, the position of the samples is related to the abundance of the micas and the "apparent illite layers" in the mixture of the disordered interstratified illite/smectite clay minerals.

The volcanic clayey siltstones, rich in calcium and iron, are projected in a distinct area, defined by a constant $\mathrm{CaO} / \mathrm{CaO}+$ $\mathrm{Na}_{2} \mathrm{O}+\mathrm{K}_{2} \mathrm{O}$ of $60 \%$. In these rocks, poor in micas and clay minerals, no trend toward the $\mathrm{K}_{2} \mathrm{O}$ pole appears. 


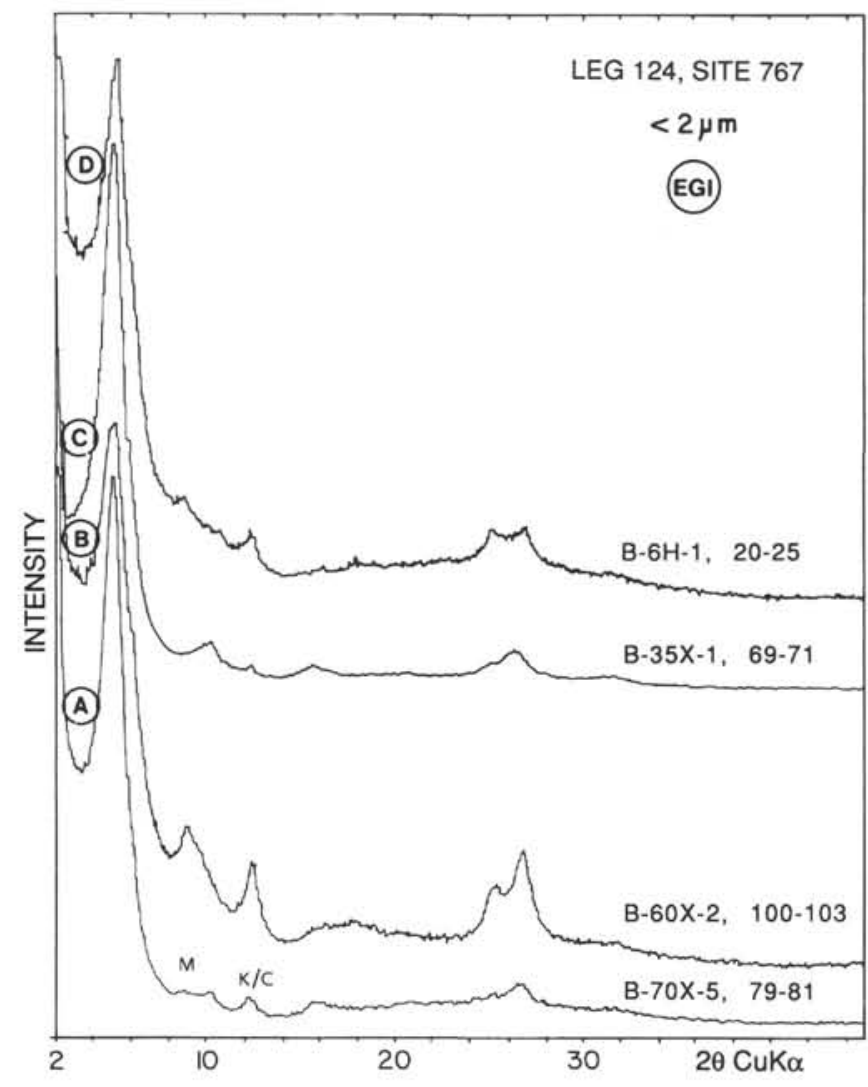

Figure 4. Diffraction profiles of the oriented ethylene-glycolated fraction (EGL) $<2 \mu \mathrm{m}$ from detrital sediments at Site 767 (Units I to III), Leg 124. Core sample numbers are at right.

The brown claystones are subdivided into three groups (Fig. $14 \mathrm{C}$ ), with increasing $\mathrm{CaO} / \mathrm{Na}_{2} \mathrm{O}$ ratio as the potassium decreases. The first group (Fig. 14C), adjacent to the K-rich sediments of the Sulu Basin, has the same position as the hemipelagic and turbiditic sediments from Site 767 (Fig. 14D). The compositions are either aluminous or magnesian. The second group, more calcic, is composed of all the iron-rich brown claystones. Less sodic than the turbiditic and hemipelagic sediments from Site 767 (Sulu Sea), their position is intermediate between that of the volcanogenic clayey siltstones of Site 768 and the interbedded claystone/siltstone from Site 767 (Fig. 14D). The third group, less potassic and the more calcic, is adjacent to the volcanogenic clayey siltstones of the Celebes Sea, but this composition is more sodic (Fig. 14D).

This projection is useful for illustrating the relative influences of the detrital and volcanogenic influxes in the sediments. The $\mathrm{K}_{2} \mathrm{O}$ pole represents the detrital potassic phases such as the micas and the disordered mixed-layer clay minerals. The $\mathrm{CaO} /$ $\mathrm{Na}_{2} \mathrm{O}$ side corresponds to the plagioclases and the $\mathrm{CaO}$ pole represents the ferromagnesian calcic silicates, such as the pyroxenes. The increasing $\mathrm{CaO} / \mathrm{Na}_{2} \mathrm{O}$ ratio as the potassium content decreases, and the lack of compositions rich in $\mathrm{Na}_{2} \mathrm{O}$ in all the sites indicate contamination by plagioclases rich in anorthite. The source of the coarse-grained volcanic material is predominantly an andesitic or basaltic magmatism.

\section{Fine-Fractions}

The mineralogical section has shown that the fine fraction $(<2 \mu \mathrm{m})$ is often a mixture of clay minerals. Disordered interstratified clay minerals predominate in detrital formations, whereas in brown claystones and in some volcanic tuff,

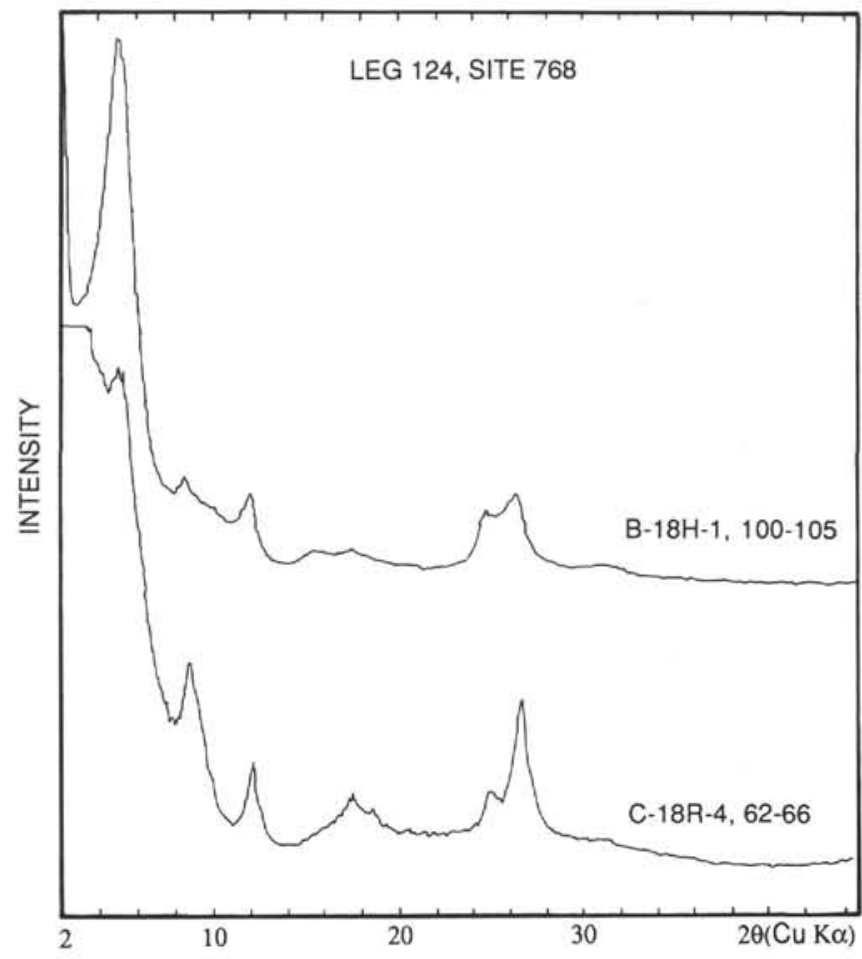

Figure 5. Diffraction profiles of the oriented ethylene-glycolated fraction (EGl) $<2 \mu \mathrm{m}$ from detrital sediments at Site 768 (Units I to III). Core sample numbers are at right.

the clay minerals are smectite rich or pure smectite. Besides these two components, some kaolinite and micas or illite are present. Quite clearly, the chemical analyses of the fine fractions (Table 8) are not those of a pure clay mineral.

Nevertheless, the chemical analyses were converted to chemical formulas, calculated on an anhydrous basis of $22+$ cations as for di- or tri- octahedral micas or clay minerals.

\section{Alkalines and Calcium Contents}

Figure 15 compares the alkalines and calcium contents of the fine fractions in the Celebes Sea sediments (Site 767). Four distinct groups are recognized:

1. A Ca-poor, Na-poor and K-rich group in turbiditic claystones or sandstones, and in one brown claystone,

2. A Ca-poor, $\mathrm{Na}-\mathrm{K}$ group, only observed in the brown claystones,

3. A Na-poor, Ca-rich group characteristic of the volcanogenic clayey silt, and

4. A Ca-Na-K-group in hemipelagic sediments or some volcanogenic clayey silts.

Figure 15 shows a complex control on the chemical composition of the fine fractions with two gaps in the $\mathrm{Ca} / \mathrm{K}$ or $\mathrm{Na} / \mathrm{K}$ ratios.

In the Sulu Sea (Fig. 16), the compositions are either calc-potassic or, more often, sodic-potassic. In the Cagayan block (Site 769) (Fig. 16) the $2-\mu \mathrm{m}$ fractions of the hemipelagic sediments are calc-potassic, with variable sodium, whereas the fine fraction $(2 \mu \mathrm{m})$ of the brown claystones are sodicpotassic.

These diagrams are significantly different. At Site 768 , the low calcium content of the fine fraction reflects that of the whole rock. But this argument is not valid for the fine fraction at Site 769. Even if some feldspar or zeolite contamination 
Table 4. Peak positions in the X-ray (XRD) profiles of clay-size fractions ( $2 \mu \mathrm{m})$ from Leg 124 sediments.

\begin{tabular}{|c|c|c|c|c|c|c|c|c|c|c|c|c|c|c|c|c|c|c|c|}
\hline & ML & $\overline{\mathrm{ML}}$ & $\mathrm{ML}$ & $\begin{array}{r}\mathrm{Sm} / \mathrm{ML} \\
(001) \\
\end{array}$ & Chl & ML & $\begin{array}{l}\mathrm{I} / \mathrm{M} \\
(001) \\
\end{array}$ & $\mathrm{Sm} / \mathrm{ML}$ & $\mathrm{K} / \mathrm{C}$ & $\begin{array}{r}\mathrm{Sm} / \mathrm{ML} \\
(003)\end{array}$ & $\begin{array}{r}\mathrm{Sm} / \mathrm{ML} \\
(003) \\
\end{array}$ & $\begin{array}{r}/ \mathrm{M} \\
(003) \\
\end{array}$ & Chl & $\mathrm{Sm} / \mathrm{ML}$ & $\mathrm{Sm} / \mathrm{ML}$ & $\mathrm{K} / \mathrm{C}$ & $\mathrm{I} / \mathrm{M}$ & $\overline{M L}$ & ML \\
\hline \multicolumn{20}{|c|}{ SITE 767 (CELEBES SEA) } \\
\hline \multicolumn{20}{|c|}{$\begin{array}{l}\text { Hemipelagic claystones an } \\
\text { interbedded turbidites }\end{array}$} \\
\hline $124-767 \mathrm{~B}-60 \mathrm{X}-2,100-103$ & & & & 17.40 & & & 9.95 & 8.86 & 7.20 & & & 5.01 & 4.75 & 4.44 & & 3.54 & 3.35 & 2.84 & \\
\hline $124-767$ B- $54-3,80-82$ & & & & 17.40 & & & 9.96 & & 7.18 & 5.64 & & 5.05 & & & 4.24 & 3.56 & 3.36 & 2.84 & 2.78 \\
\hline $124-767 \mathrm{~B}-40 \mathrm{X}-3,134-136$ & & & & 17.38 & & & & 8.78 & 7.24 & Jor & & & & & 4.28 & 3.56 & 3.38 & 2.82 & \\
\hline $124-767 \mathrm{~B}-50 \mathrm{X}-3,24-28$ & & & & 17.22 & & & & 8.66 & 7.27 & 5.57 & & & & & & 3.55 & 3.36 & 2.83 & \\
\hline $\begin{array}{l}\text { 124-767B-50X-3, 24-28 } \\
\text { Volcanogenic clavey siltstones }\end{array}$ & \multicolumn{9}{|c|}{$\begin{array}{l}\text { 124-767B-50X-3, 24-28 } \\
\text { Volcanogenic clayey siltstones }\end{array}$} & 5.60 & & 5.03 & 4.80 & 4.37 & & 3.55 & 3.35 & 2.84 & \\
\hline $\begin{array}{l}\text { Volcanogenic clayey siltstones } \\
124-767 \mathrm{~B}-35 \mathrm{X}-1,69-71\end{array}$ & & & & 17.17 & & & & 8.63 & 7.17 & 5.60 & 5.49 & & & & & 3.52 & 3.37 & 2.84 & 2.76 \\
\hline $124-767 \mathrm{~B}-22 \mathrm{X}-1,69-71$ & & & & 16.99 & & & 10.02 & 8.50 & 7.24 & 5.55 & 3.49 & & & & & 3.56 & 3.35 & 2.84 & 2.76 \\
\hline $\begin{array}{l}\text { Brown claystones } \\
124-767 \mathrm{C}-8 \mathrm{R}-1,73-75\end{array}$ & & & & 16.93 & & & 10.00 & 8.53 & & 5.55 & & & & & & & 3.34 & & 2.79 \\
\hline $124-767 \mathrm{C}-78 \mathrm{X}-\mathrm{CC}, 10-13$ & & & & 16.89 & & & 9.98 & 8.54 & 7.21 & 5.59 & 5.54 & 5.03 & & & 4.19 & 3.58 & 3.33 & & 2.78 \\
\hline $124-767 \mathrm{C}-75 \mathrm{X}-1,1127-129$ & & & & 16.85 & & & 9.92 & 8.64 & 7.21 & 5.50 & 34 & 5.02 & 4.77 & & 4.17 & 3.56 & 3.33 & 2.82 & 2.77 \\
\hline $124-767 \mathrm{C}-9 \mathrm{R}-2,88-93$ & & & & 17.06 & & & 9.92 & 8.51 & 7.12 & 5.61 & & 5.02 & 4.71 & 4.47 & 4.23 & ..50 & 3.35 & 2.80 & 2.17 \\
\hline $124-767 \mathrm{C}-6 \mathrm{R}-1,15-17$ & & & & 16.95 & & & 10.02 & 8.49 & 7.20 & 5.57 & & & & 4.45 & 4.22 & & 3.34 & & 2.78 \\
\hline $124-767 \mathrm{C}-6 \mathrm{R}-3,46-48$ & & & & 16.92 & & & 9.65 & 8.50 & & 5.62 & & & & & 4.23 & & 3.36 & 2.80 & \\
\hline $124-767 \mathrm{C}-8 \mathrm{R}-1,73-75$ & & & & 16.91 & & & & 8.52 & & 5.62 & & & & & 4.24 & & 3.37 & 2.81 & \\
\hline $124-767 C-7 R-C C, 6-8$ & & & & 16.80 & & 11.29 & & 8.47 & & 5.59 & & & & & 4.22 & & 3.35 & 2.79 & \\
\hline \multicolumn{20}{|c|}{$\begin{array}{l}\text { SITE } 768 \text { (SULU SEA) } \\
\text { Interbedded claystones and siltstones }\end{array}$} \\
\hline $\begin{array}{l}\text { Interbedded claystones and sits } \\
124-768 \mathrm{C}-6 \mathrm{R}-2,20-23\end{array}$ & & & & 17.46 & & & 9.95 & 8.73 & 7.15 & & & 5.01 & 4.77 & & & 3.55 & 3.33 & & \\
\hline $124-768 \mathrm{C}-23 \mathrm{R}-1,92-94$ & & & & 17.29 & & & 9.94 & 8.44 & 7.19 & 5.61 & & 4.97 & 4.17 & & 3.55 & 3.33 & 3.93 & & \\
\hline $124-767 \mathrm{~B}-18 \mathrm{H}-1,100-105$ & & & & 17.28 & & & 9.99 & 8.75 & 7.24 & 5.63 & & 5.00 & 4.79 & & 4.21 & 3.56 & 3.35 & & 2.76 \\
\hline $124-768 \mathrm{~B}-28 \mathrm{X}-1,108-113$ & & & & 17.07 & & & 9.93 & 8.93 & 7.18 & & 5.38 & 5.00 & 4.76 & & & 3.53 & 3.34 & 2.87 & 2.80 \\
\hline $124-768 \mathrm{C}-11 \mathrm{R}-5,15-17$ & & & & 17.23 & & 12.23 & 9.91 & 8.60 & 7.15 & 5.55 & & 4.99 & 4.76 & & & 3.54 & 3.33 & 2.85 & \\
\hline $124-768 \mathrm{~B}-33 \mathrm{X}-2,130-134$ & 30.18 & 24.69 & & 17.21 & 14.97 & & 9.94 & & 7.17 & & 5.37 & 5.01 & 4.79 & & & 3.55 & 3.34 & & \\
\hline $124-768 \mathrm{C}-18 \mathrm{R}-4,13-16$ & & 26.35 & 18.21 & & 14.78 & 12.66 & 9.96 & & 7.20 & & & 5.03 & 4.79 & & & 3.55 & 3.35 & & \\
\hline $124-768 \mathrm{C}-29 \mathrm{R}-4,13-16$ & & 26.75 & 18.59 & 16.51 & 14.90 & & 9.91 & & 7.17 & & & 5.00 & 4.77 & & & 3.54 & 3.34 & 2.83 & \\
\hline $\begin{array}{l}\text { Volcanic material } \\
124-768 \mathrm{C}-39 \mathrm{R}-4,24-27\end{array}$ & & & & & & & & & & 567 & & & & & 429 & & & 889 & \\
\hline $\begin{array}{l}124-768 \mathrm{C}-39 \mathrm{R}-4,24-27 \\
124-768 \mathrm{C}-50 \mathrm{R}-3,55-57\end{array}$ & 29.67 & & & $\begin{array}{l}16.99 \\
16.68\end{array}$ & & 12.79 & 9.94 & $\begin{array}{l}8.53 \\
8.40\end{array}$ & 7.25 & 5.63 & & 4.97 & & & 4.25 & & $\begin{array}{l}3.37 \\
3.31\end{array}$ & 2.82 & \\
\hline $124-768 \mathrm{C}-60 \mathrm{R}-1,2-4$ & & & & 16.87 & & & 9.98 & 8.55 & 7.13 & 5.56 & & & & & 4.21 & & 3.34 & 2.83 & \\
\hline \multicolumn{20}{|c|}{ SITE 769 (CAGAYAN BLOCK) } \\
\hline Hemipelagic claystones & & & & & & & & & & & & & & & & & & & \\
\hline $\begin{array}{l}124-769 \mathrm{~B}-16 \mathrm{H}-4,31-33 \\
124-769 \mathrm{~B}-20 \mathrm{H}-6,31-35\end{array}$ & & 19.62 & $\begin{array}{l}17.23 \\
17.37\end{array}$ & & 14.36 & $\begin{array}{l}10.05 \\
10.05\end{array}$ & & 8.62 & $\begin{array}{l}7.25 \\
7.20\end{array}$ & & & $\begin{array}{l}4.98 \\
4.98 \\
\end{array}$ & 4.75 & & 4.12 & $\begin{array}{l}3.55 \\
3.56 \\
\end{array}$ & $\begin{array}{r}3.35 \\
3.34 \\
\end{array}$ & $\begin{array}{r}2.84 \\
2.81\end{array}$ & 2.81 \\
\hline
\end{tabular}

NB: ML : Mixed-layer clay minerals, Sm/Ml : Mixed-layer clay minerals and smectite; Chl: Chlorite; l/M : Illite/Mica; Cl: Clinoptilolite; K/C : Kaolinite/Chlorite; M: mica. 


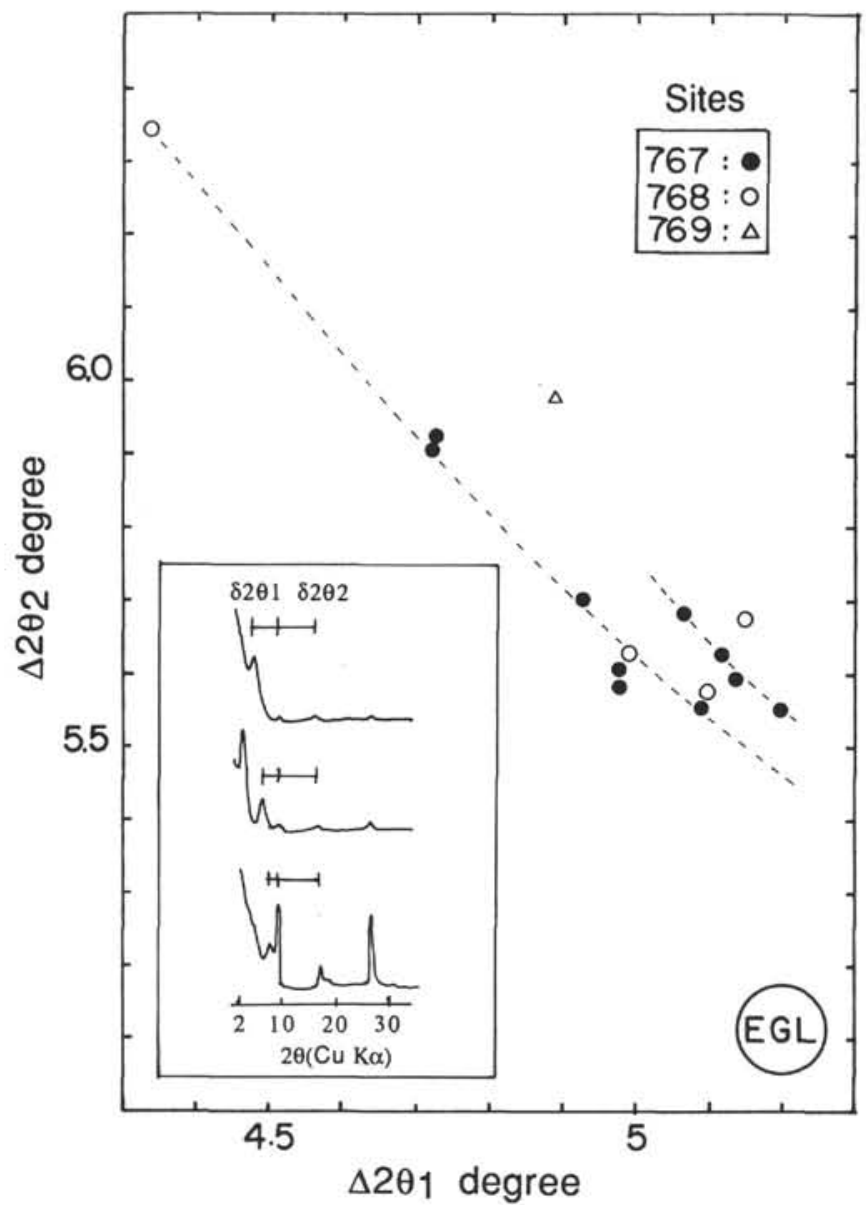

Figure 6. Diagram from Watanabe (1981) showing the disordered nature of the interstratified clays minerals in the clay size fraction $(<2$ $\mu \mathrm{m})$ of the clastics sediments from Leg 124 .

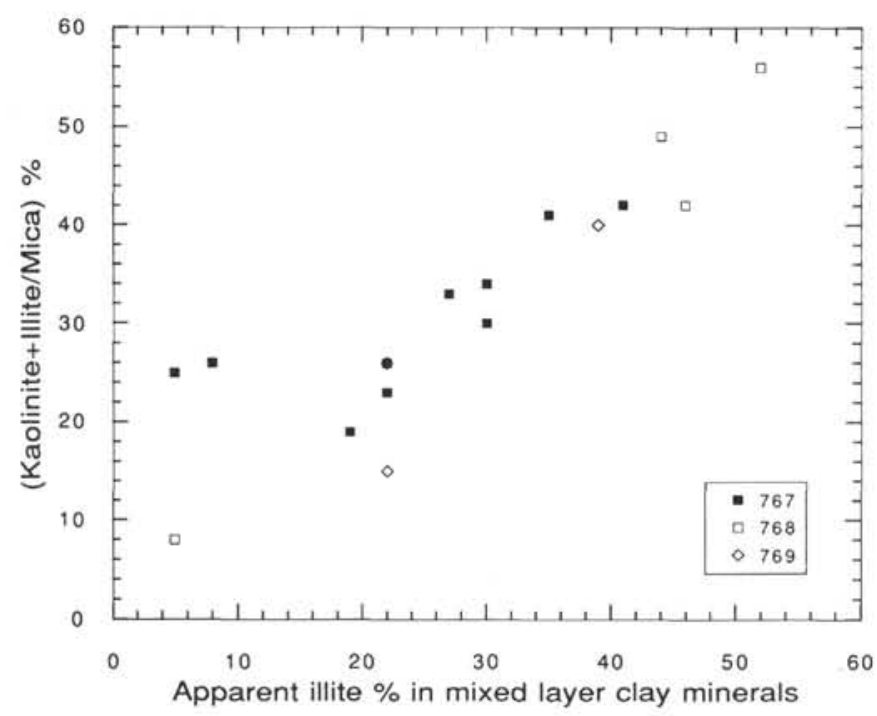

Figure 7. Relation between the apparent illite percentage in the disordered interstratified clay minerals and the amount of micas and kaolinite in the clay- size fractions $(<2 \mu \mathrm{m})$ in the sediments of Leg 124 .

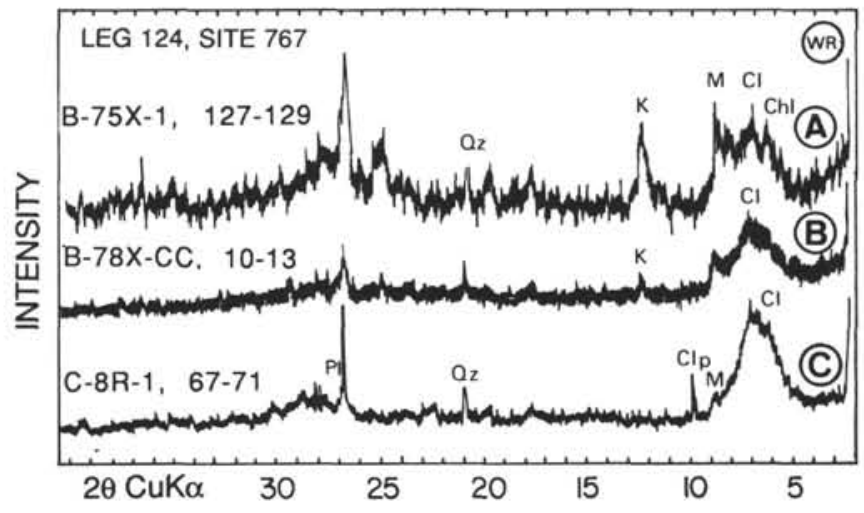

Figure 8. Whole-rock diffraction profiles of some brown claystones (Leg 124, Site 767, Unit IV). Note: Chl: Chlorite; Cl: clay; Clp: Clinoptilolite; K/C: kaolinite/chlorite; M: Mica; PI: plagioclase; Qz: quartz. Core sample numbers are at left.

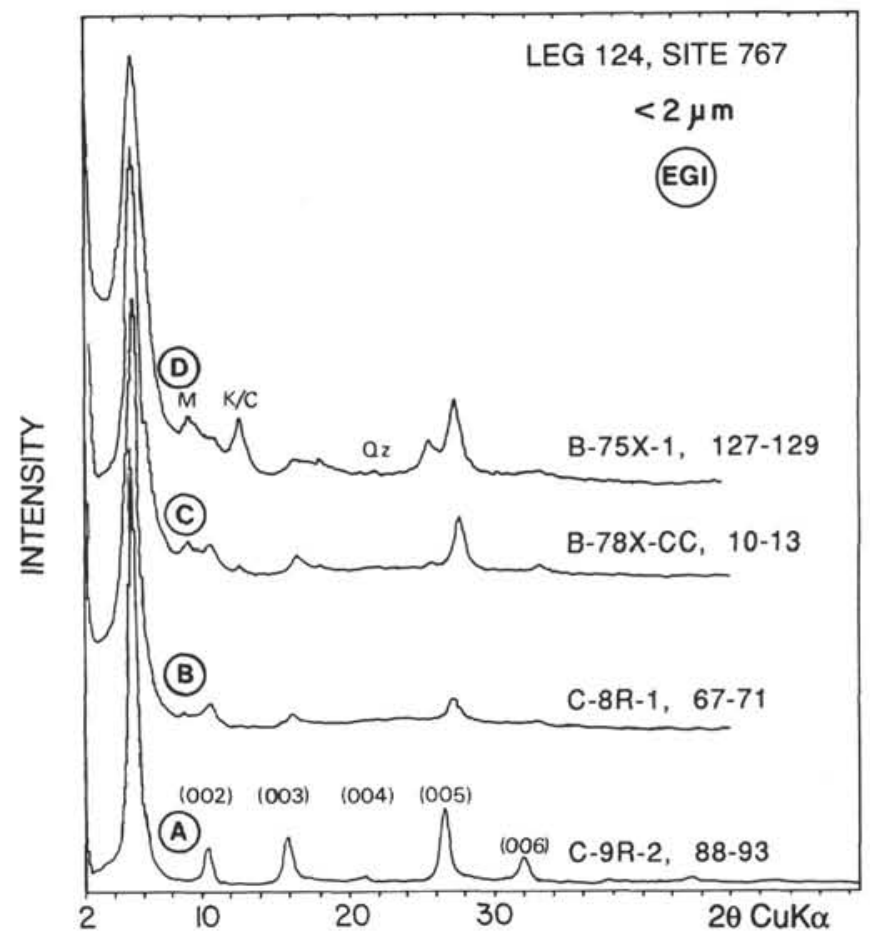

Figure 9. Diffraction profiles of some oriented ethylene-glycolated (EGL) fractions $<2 \mu \mathrm{m}$ from brown claystones (Leg 124, Site 767, Unit IV). Note: K/C: kaolinite/chlorite; M: Mica; Qz: quartz; (001): basal reflections. Core sample numbers are at right.

cannot be completely excluded, the calcic composition may indicate the presence of some Ca-smectite. Compared to the whole-rock $\mathrm{CaO} / \mathrm{Na}_{2} \mathrm{O} / \mathrm{K}_{2} \mathrm{O}$ compositions, some fine fractions, for example in the brown claystones from Sites 768 and 769 , appear to be enriched in sodium.

\section{Magnesium and Iron Contents}

The relative magnesium and iron contents of the fine fractions follow the composition of the rocks, as shown by the parallelism of the broken lines, down in the holes (Fig. 17). In both cases, the clay-size fractions concentrate the magnesium, and this effect is particularly strong at Site 767 . The uptake of magnesium in the sediments deduced from the concentration-depth profiles, is attributed to volcanic matter alteration, both in sediments and in basalts (Gieskes and Lawrence, 1981), through the formation of 


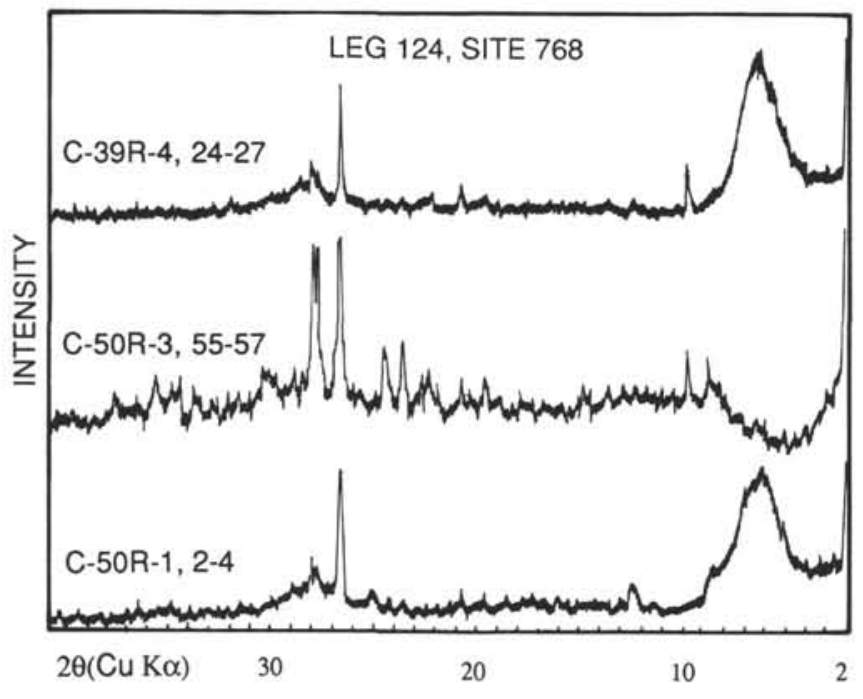

Figure 10. Diffraction profiles of some volcanic bed from Units III and IV at Site 768, Leg 124. (Cl: clay; Clp: clinoptilolite; K/C: kaolinite/ chlorite; $\mathrm{Ph}$ : phillipsite; Pl: Plagioclase; Qz: quartz). Core sample numbers are at left.

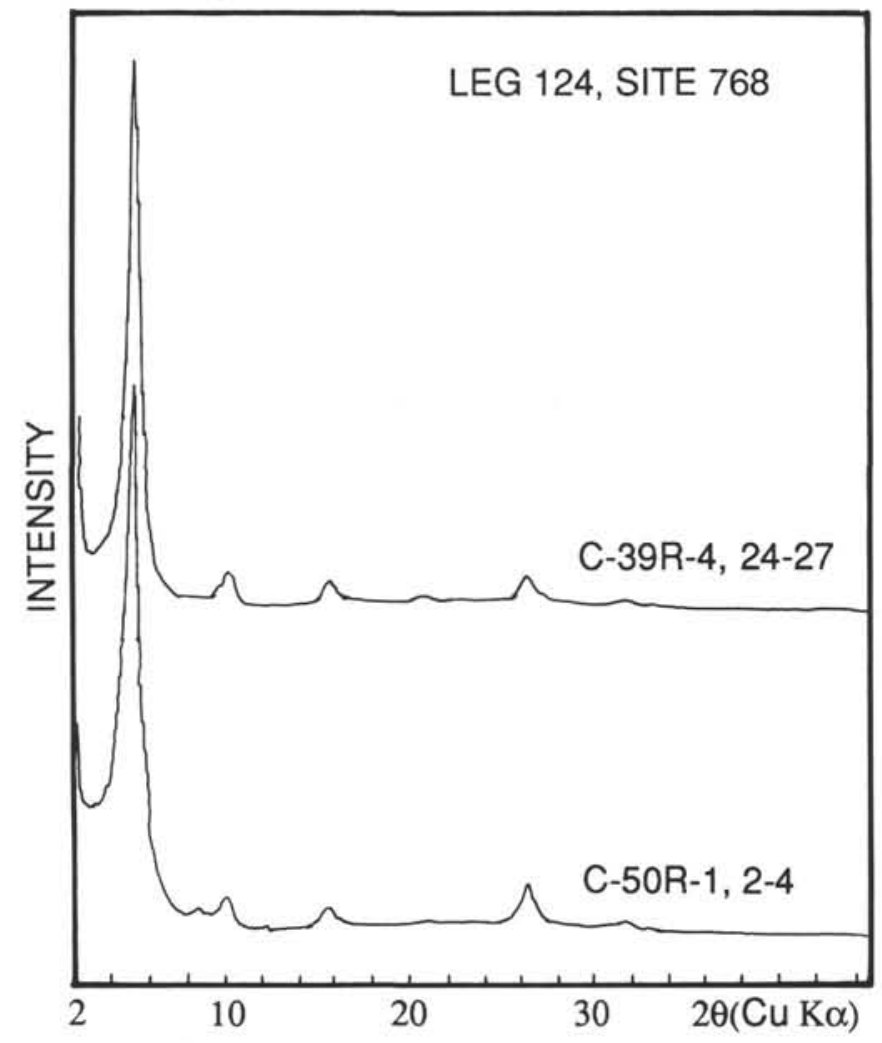

Figure 11. Diffraction profiles of some oriented and ethylene-glycolated (EGL) fractions $<2 \mu \mathrm{m}$ from volcanic beds (Leg 124, Site 768, Units III and IV). Core sample numbers are at right.

a magnesian smectite (Perry et al., 1976; Kastner and Gieskes, 1976; Lawrence et al., 1979).

\section{Classification}

The variations described are used to establish a classification of the chemical analyses of the clay-size fractions (Table 9).

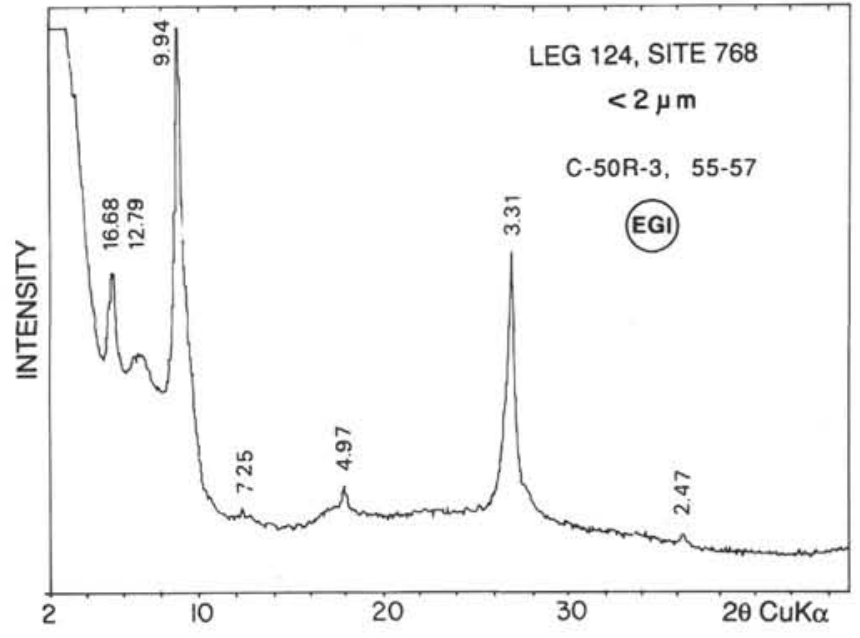

Figure 12. Diffraction profile of the oriented and ethylene-glycolated (EGL) fraction $<2 \mu \mathrm{m}$ from the pyroclastic unit IV at Site 768 (Sample 124-768C-50R-3, 55-57 cm).

The first group, composed of the low-potassium fractions, is thought to represent the sediments the less contaminated by terrestrial influx. They are magnesium rich, with the exception of one rich in pyrite (Sample 124-767B-10H-5, 95-97 cm). The silicon, calcium, and sodium contents are high. This group is composed of the volcanogenic clayey siltstones from Site 767 (Unit I and II), contaminated by andesitic materials, and by a volcanic tuff (Sample 124-768C-39R-4, 24-27 cm).

In the second group, high aluminum contents are encountered at all sites. All are potassium rich and, with the exception of two samples, iron dominates magnesium. The silica content is low. These analyses correspond to samples rich in micas, kaolinite, and disordered interstratified clay minerals.

Aluminum-poor fractions constitute the third group. The samples are rich in sodium and silica. These properties suggest contamination by some zeolite or albitic feldspar, although these minerals are not detected in the X-ray diffraction profiles. Two samples are brown claystones. One is the special volcanic layer (Sample 124-768C-50R-3, 55-57 cm) with ordered mixed-layer clay minerals that cannot be compared to the other samples.

The last group includes the samples with intermediate or low aluminum content and not poor in potassium. A few are sodic and the proportion seems to be lower than in the other groups. They may be magnesian. Higher values in iron are correlated with lower values in aluminum. These mixed characters probably reflect different contributions to the sediments.

\section{Volcanic vs. Terrestrial Influxes}

To recognize the different influences, two ratios are considered:

1. $\mathrm{Mg} / \mathrm{K}+\mathrm{Fe}$ : from the previous description, this ratio increases in the volcanogenic sediments and decreases with a high detrital contribution.

2. $\mathrm{Al} / \mathrm{Na}+\mathrm{Si}$ : aluminum-rich values are typical of detrital sediments with large terrestrial influx. The zeolite presence in the fine fraction is taken into account through the ratio.

In summary, volcanogenic influence should yield a high $\mathrm{Mg} / \mathrm{K}+\mathrm{Fe}$ ratio and a low $\mathrm{Al} / \mathrm{Na}+\mathrm{Si}$ ratio, and the reverse in the case of a detrital influx. Calcium was neglected because it 
Table 5. Chemical compositions (wt \%) of detrital sediments from Leg 124 . $(\mathrm{S}=100 \%)$.

\begin{tabular}{|c|c|c|c|c|c|c|c|c|c|c|c|c|c|}
\hline $\begin{array}{l}\text { Core, section, } \\
\text { interval (cm) }\end{array}$ & Lith $^{1}$. & $\mathrm{SiO}_{2}$ & $\mathrm{TiO}_{2}$ & $\mathrm{Al}_{2} \mathrm{O}_{3}$ & $\mathrm{Fe}_{2} \mathrm{O}_{3}$ & $\mathrm{MgO}$ & $\mathrm{MnO}$ & $\mathrm{CaO}$ & $\mathrm{Na}_{2} \mathrm{O}$ & $\mathrm{K}_{2} \mathrm{O}$ & $\mathrm{P}_{2} \mathrm{O}_{5}$ & $\mathrm{SO}_{3}$ & a \\
\hline \multicolumn{14}{|l|}{ Site 767 (Celebes Sea) } \\
\hline B-6H-1, 20-25 & vCS & 46.84 & 0.73 & 16.93 & 9.42 & 3.49 & \multirow{8}{*}{0.07} & 5.10 & 7.65 & 2.11 & & 1.18 & 6.56 \\
\hline B-10H-5, 95-97 & VCS & 43.07 & 0.74 & 13.68 & 18.38 & 2.19 & & 4.07 & 3.51 & 1.72 & & 10.23 & 2.33 \\
\hline $3 \mathrm{~B}-22 \mathrm{X}-1,18-23$ & VCS & 49.11 & 0.96 & 17.21 & 9.70 & 5.12 & & 5.22 & 5.80 & 1.66 & & 1.23 & 3.99 \\
\hline B-35X-1, 69-71 & VCS & 55.59 & 0.89 & 18.43 & 8.62 & 2.41 & & 1.71 & 4.95 & 3.50 & & 1.78 & 2.11 \\
\hline B- $40 X-3,134-146$ & C & 56.71 & 1.07 & $\begin{array}{l}18.69 \\
\end{array}$ & 9.51 & 3.73 & & 2.27 & 3.20 & 1.39 & & 1.91 & 1.50 \\
\hline B-50X-3, $24-28$ & HMP & 52.07 & 1.02 & 19.87 & 9.91 & 2.76 & & 3.97 & 3.76 & 1.97 & & 1.78 & 2.89 \\
\hline B-54X-3, 80-82 & $\mathrm{TB}$ & 59.43 & 0.61 & 16.58 & 8.46 & 2.39 & & 1.04 & 4.09 & 2.40 & & 1.62 & 3.38 \\
\hline B-60X-2, $100-103$ & $\mathrm{~TB}$ & 61.23 & 0.88 & 16.75 & 10.03 & 2.38 & & 0.76 & 1.70 & 2.88 & & 2.66 & 0.71 \\
\hline B-70X-5, 79-81 & HMP & 57.35 & 0.89 & 18.58 & 8.72 & 6.22 & \multirow[b]{2}{*}{0.61} & 1.91 & 2.48 & 2.27 & & \multirow[t]{2}{*}{1.19} & 0.38 \\
\hline B-74X-06, 61-63 & HMP & 58.31 & 0.86 & 21.58 & 9.11 & 2.91 & & 1.21 & 1.67 & 3.35 & & & 0.39 \\
\hline B-75X-1, $127-129$ & PC & 58.23 & 0.67 & 22.50 & 9.43 & 2.47 & \multirow[t]{2}{*}{0.45} & 0.84 & 1.24 & 3.75 & \multirow{5}{*}{0.45} & & 0.42 \\
\hline B- $75 X-4,85-87$ & PC & 58.38 & 0.93 & 22.54 & 9.34 & 2.52 & & 1.10 & 1.35 & 3.38 & & \multirow{4}{*}{$\begin{array}{l}0.22 \\
0.33\end{array}$} & 0.46 \\
\hline B- $76 \times-4,72-74$ & PC & 58.63 & 0.73 & 17.42 & 12.22 & 2.97 & 0.72 & 2.60 & 1.78 & 2.14 & & & 0.35 \\
\hline B-78X-1,71-73 & PC & 60.09 & 0.88 & 19.57 & 7.42 & 3.67 & 0.70 & 3.20 & 2.19 & 0.95 & & & 1.12 \\
\hline B- $78 \mathrm{X}-\mathrm{CC}, 10-13$ & PC & 59.13 & 0.97 & 18.42 & 10.55 & 2.48 & 1.14 & 1.80 & 1.55 & 3.44 & & & 0.19 \\
\hline C- $6 \mathrm{R}-01,15-17$ & PC & 61.17 & 0.67 & 20.31 & 6.52 & 4.44 & 0.45 & 2.61 & 2.17 & 0.97 & \multirow{3}{*}{0.39} & & 0.68 \\
\hline C-6R-01, 99-101 & PC & 59.00 & 0.65 & 18.53 & 10.09 & 3.01 & 1.86 & 2.08 & 1.59 & 2.51 & & & 0.31 \\
\hline C- $6 \mathrm{R}-3,46-48$ & PC & 61.89 & 0.75 & 19.59 & $\begin{array}{r}7.50 \\
7.50\end{array}$ & 3.05 & \multirow{3}{*}{2.37} & 3.29 & 2.36 & 1.18 & & \multirow{3}{*}{\multicolumn{2}{|c|}{$\begin{array}{l}0.38 \\
0.93 \\
0.78\end{array}$}} \\
\hline C- $7 \mathrm{R}-2,67-70$ & PCw & 57.91 & 0.99 & 22.51 & 5.78 & 3.54 & & 2.17 & 1.79 & 2.02 & & & \\
\hline C- $7 \mathrm{R}-02,67-70$ & $\mathrm{PCr}$ & 57.39 & 0.86 & 22.89 & 10.38 & 2.29 & & 1.65 & 0.84 & 2.92 & & & \\
\hline C-7R-CC, 6-8 & PC & 60.80 & 0.96 & 20.41 & 7.54 & 3.52 & & 3.37 & 2.57 & 0.85 & \multirow[b]{2}{*}{0.30} & \multirow{5}{*}{0.28} & \\
\hline C- $8 \mathrm{R}-1,34-36$ & PC & 61.33 & 0.58 & 16.99 & 9.49 & 2.61 & 1.56 & 2.84 & 2.02 & 1.99 & & & 0.29 \\
\hline C-8R-1, 67-71 & PC & 60.79 & 0.68 & 16.67 & 10.37 & 2.43 & 1.71 & 2.73 & 1.91 & 2.38 & & & 0.33 \\
\hline C-8R-1, 73-75 & PC & 61.06 & 1.01 & 19.53 & 6.50 & 3.97 & 0.66 & 2.98 & 2.05 & 1.01 & 0.52 & & 0.44 \\
\hline C-8R-1,94-96 & PC & 60.19 & 0.85 & 17.65 & 10.70 & 2.96 & 0.98 & 2.48 & 1.65 & 2.31 & & & 0.29 \\
\hline \multicolumn{14}{|l|}{ Site 768 (Sulu Sea) } \\
\hline B- $18 \mathrm{H}-1,100-105$ & ICS & 48.22 & 0.81 & 18.63 & 8.60 & 3.59 & \multirow{12}{*}{0.49} & 0.67 & 8.52 & 2.80 & & \multirow{12}{*}{$\begin{array}{l}1.34 \\
1.21 \\
2.41 \\
1.74 \\
2.01 \\
0.53 \\
1.27 \\
0.54 \\
0.34\end{array}$} & 8.14 \\
\hline B-28X-1, 108-113 & ICS & 55.74 & $\begin{array}{l}.01 \\
0.78\end{array}$ & 16.87 & 7.75 & 2.82 & & 0.33 & 5.13 & 3.47 & & & 5.29 \\
\hline B-33X-2, 130-134 & ICS & 56.34 & 0.87 & 18.31 & 8.86 & 3.14 & & 0.68 & 3.71 & 3.80 & & & 3.29 \\
\hline C-1R-3, 113-115 & ICS & 60.73 & 0.77 & 16.16 & 8.33 & 3.11 & & 0.26 & 2.69 & 3.33 & & & 2.20 \\
\hline C-6R-2, 20-23 & ICS & 62.01 & 0.84 & $\begin{array}{l}10.10 \\
15.05\end{array}$ & $\begin{array}{l}0.35 \\
10.39\end{array}$ & 3.29 & & 0.60 & 2.11 & 2.66 & & & 1.31 \\
\hline C-11R-5, 15-17 & ICS & 66.41 & 0.73 & 13.07 & 7.66 & 3.55 & & 0.45 & 2.10 & 2.73 & & & 1.29 \\
\hline C- $18 R-4,62-66$ & ICS & 58.66 & 0.98 & 19.05 & 9.56 & 3.81 & & 0.81 & 2.09 & 3.61 & & & 0.88 \\
\hline C-23R-1, 92-94 & ICS & 58.07 & 1.04 & 21.03 & 9.70 & 3.36 & & 0.42 & 1.58 & 4.26 & & & 0.54 \\
\hline C- $29 \mathrm{R}-4,13-16$ & ICS & 64.67 & 0.71 & 16.13 & 7.70 & 2.87 & & 0.64 & 2.01 & 3.12 & & & 0.88 \\
\hline C- 39 R $-4,24-27$ & VT & 63.93 & 0.55 & 17.50 & 7.93 & 3.02 & & 2.32 & 2.03 & 1.68 & & & 0.52 \\
\hline C- $50 \mathrm{R}-1,2-4$ & VT & 59.80 & 0.57 & 16.19 & 10.91 & 3.42 & & 3.16 & 2.04 & 3.36 & & & 0.21 \\
\hline C-50R-3, 55-57 & VP & 58.89 & 0.77 & 14.42 & 11.68 & 2.81 & & 4.90 & 1.96 & 4.26 & & & 0.22 \\
\hline \multicolumn{14}{|l|}{ Site 769 (Cagayan Block) } \\
\hline B- $16 \mathrm{H}-4,31-33$ & HMP & 48.52 & 0.80 & 18.53 & 8.36 & 3.42 & & 1.36 & 8.18 & 2.75 & & \multirow{5}{*}{0.64} & 8.09 \\
\hline B-20H-6, 31-35 & HMP & 50.94 & 0.83 & 19.00 & 7.48 & 3.69 & & 2.27 & 6.37 & 2.99 & & & 5.78 \\
\hline B-30X-CC, 6-8 & PC & 58.03 & 0.51 & 17.07 & 9.08 & 5.52 & 0.57 & 1.51 & 3.01 & 2.91 & 0.41 & & 1.39 \\
\hline B-30C-CC, $23-25$ & PC & 56.09 & 0.71 & 17.78 & 8.58 & 5.03 & 0.31 & 1.88 & 3.55 & 3.92 & & & 2.15 \\
\hline C- $2 \mathrm{R}-5,133-136$ & PC & 27.66 & 0.32 & 8.20 & 5.86 & 2.78 & & 1.32 & 24.59 & 1.96 & & & 27.30 \\
\hline
\end{tabular}

\footnotetext{
${ }^{1}$ Lith.: lithology; ICS: interbedded claystone/siltstone; TB: turbidite; HMP: hemipelagic claystone; VCS: volcanogenic claystone/siltstone; VP: volcanic pyroclatite; VT: volcanic tuff; C: claystone.
}

is only characteristic of the Site 767 fine fraction. It is probably located in calcium smectite or in a sodic-calcic phillipsite, so perhaps should be added to the sum $\mathrm{Na}+\mathrm{Si}$.

\section{Fine-Fractions}

The chemical compositions of the fine fractions from all the sites are shown in Figure 18. The volcanogenic clayey siltstones (Site 767, Celebes Sea), with a high $\mathrm{Mg} / \mathrm{K}+\mathrm{Fe}$ ratio, occupy an area distinct from that of the hemipelagic and interbedded claystones/siltstones (Site 768, Sulu Sea and Site 769 , Cagayan block) with a low $\mathrm{Mg} / \mathrm{K}+\mathrm{Fe}$ and a high $\mathrm{Al} /$ $\mathrm{Na}+\mathrm{Si}$ ratio. Turbidites or sediments of the two previous groups are intermediate between these two extremes.

The brown claystones with a low $\mathrm{Mg} / \mathrm{K}+\mathrm{Fe}$ ratio, if they are iron-rich, are on the low $\mathrm{Al} / \mathrm{Na}+\mathrm{Si}$ side. If they are contaminated by the detrital influx, they are on the right side. A brown claystone, rich in clinoptilolite, plots near the volcanogenic clayey siltstones (Site 767) and the volcanic tuff (Site 768), suggesting some volcanic contamination. A white interbed in the brown claystones is located in the volcanogenic clayey siltstone area.

\section{Brown Claystones}

Because the brown claystones are rich in clay minerals and particularly in smectite, the bulk-rock compositions are projected on the same diagram for comparison. Two trends characterize the projection (Fig. 19).

The subhorizontal trend links the iron-rich compositions on the left side to aluminum-rich compositions on the right side. Comparison with the $\mathrm{CaO} / \mathrm{Na}_{2} \mathrm{O} / \mathrm{K}_{2} \mathrm{O}$ projection (Fig. $14 \mathrm{C}$ ) shows that the potassium content increases relative to the sodium and calcium values along the trend. From left to right, the detrital influence is more important in the brown claystones sediments.

Along the vertical trend the iron content decreases, whereas the magnesium and silicon values increase. The vertical trend ends in the area of projection of the volcanic beds or volcanogenic sediments (Fig. $14 \mathrm{C}$ ). In the $\mathrm{CaO} / \mathrm{Na}_{2} \mathrm{O}$ / 

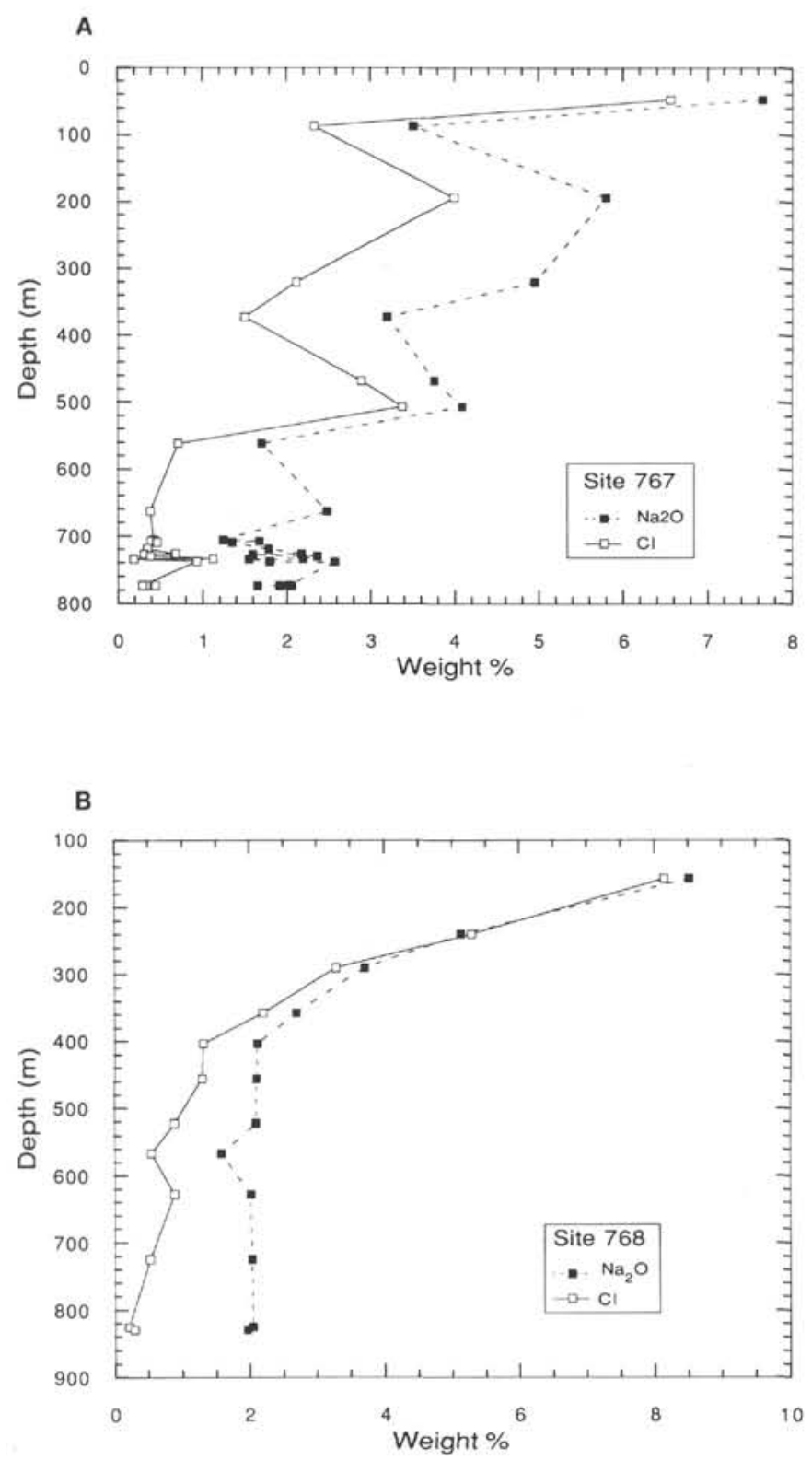

Figure 13. $\mathrm{Na}_{2} \mathrm{O}$ and $\mathrm{Cl}$ (wt\%) variations with depth in the bulk rocks analyses of sediments from Leg 124. A. Site 767. B. Site 768.

$\mathrm{K}_{2} \mathrm{O}$ projection, this trend runs from the central group to the low- potassium group.

From these two figures it may be concluded that the marine pelagic sedimentation, represented by the iron-rich brown claystones, is perturbed either by a detrital influx that increases the aluminum and potassium content of the sediments, or by volcanic influxes. The latter, particularly rich in basic plagioclase, increases the calcium, sodium, and more imperceptibly the silicon content of the sediments. The parallel increase in magnesium relative to the iron appears to be a second criterion for recognizing the volcanic contamination in the sediments. If correct, this interpretation leads to the conclusion that the two light pinkish brown claystones from Site 769 (Cagayan block, Table 1B), associated with the $\mathrm{K}$-rich group in the $\mathrm{CaO} / \mathrm{Na}_{2} \mathrm{O} / \mathrm{K}_{2} \mathrm{O}$ projections (Fig. $14 \mathrm{C}$ ) but localized on the vertical trend in Fig. 19, are pelagic sediments contaminated by volcanic material of acid composition.

\section{DISCUSSION}

The sedimentation into the three basins changes from a pelagic environment, represented by brown claystones, to a back-arc environment in which develops a detrital sedimentation, more or less contaminated by volcanic influxes.

\section{Heritage}

The continental heritage is composed of a coarse-grained fraction of quartz, micas and kaolinite, added to a fine-fraction $(2 \mu \mathrm{m})$ of various clay minerals in which the disordered interstratified clay minerals are dominant. Mixed-layer components in sediments are recycled from older sediments.

Volcanic material, scattered in the sediments, is not easy to characterize. The coarse-grained ferromagnesian minerals and the fine fractions of volcanic shards and ashes rarely show up in the X-ray diffraction profiles. More ambiguously, the volcanic shards and ashes are indirectly detected through their alteration products. Finally, the large chemical variations of the volcanic material, from basic to acid compositions, complicate the problem. The extreme difficulties arise about the smectite origin, as this mineral can be of continental or volcanic origin, primary or secondary.

In these sites, in sediments devoid of calcite, plagioclase is the most useful marker of the volcanic contribution. The abundance of plagioclases is independent of the terrestrial contribution, suggesting a dominant volcanic origin. The clearness of the plagioclase under the microscope indicates that it was not exposed to a long terrestrial alteration. The sediments are more calcic. As a result of a fine-grained volcanic contamination, the clay fraction in the sediments increases and the magnesium is often enriched relative to the iron content in the clay-size fraction of the sediments.

The dual contributions to the sedimentary basins produced interbedded sediments with clay-size fractions enriched in either disordered mixed-layer minerals or in smectite. Such mineralogical contrasts are known in continental series. In the Upper Cretaceous Pierre Shale (Great Plains, U.S.A.), randomly interstratified illite/smectite with $80 \%-40 \%$ smectite layers is present in shales, with pure smectite occurring in bentonites (Schultz, 1978). The same distribution is described in the unmetamorphosed section of the Upper Cretaceous Mancos shale (Colorado) (Nadeau and Reynolds, 1981). In Miocene profiles of the Carpathian foredeep, randomly interstratified illite/smectite characterized the claystones from brackish to hypersaline environments, whereas pure smectite is present in vitric tuff layers (Srodon, 1984).

\section{Diagenesis}

\section{Zeolites}

Zeolites are the most obvious indication that diagenetic recrystallization has occurred. Phillipsite is present in volcanogenic silty claystones of Miocene and Pliocene age at Site 767 (Celebes Sea), and in some brown claystones of the Cagayan block (Site 769). This zeolite is absent in the typical detrital sediments. Clinoptilolite was recognized in a volcanic tuff and in pyroclastic material at Site 768, and in some brown claystones at Site 767. The clinoptilolite is restricted to samples devoid of kaolinite.

Clearly, the occurrences of zeolites indicate that they are restricted to volcanic or volcanogenic contaminated materials. Phillipsite is ubiquitous in the volcanic ashes and tuffs above 300 mbsf at the different sites (Desprairies et al., 1990, this volume). By analogy, the occurrences in our samples may indicate the presence of vitric clasts within the detrital sedi- 
Table 6. Chemical classification of the detrital sediments from Leg 124 (analyses corrected for $\mathrm{NaCl}$ ).

\begin{tabular}{|c|c|c|c|c|c|c|c|c|c|c|c|}
\hline $\begin{array}{l}\text { Core, section }{ }^{1} \\
\text { interval }(\mathrm{cm})\end{array}$ & Lith. & $\mathrm{SiO}_{2}$ & $\mathrm{TiO}_{2}$ & $\mathrm{Al}_{2} \mathrm{O}_{3}$ & $\mathrm{Fe}_{2} \mathrm{O}_{3}$ & $\mathrm{MgO}$ & $\mathrm{MnO}$ & $\mathrm{CaO}$ & $\mathrm{Na}_{2} \mathrm{O}$ & $\mathrm{K}_{2} \mathrm{O}$ & $\mathrm{SO}_{3}$ \\
\hline \multicolumn{12}{|c|}{ Cao poor, $\mathrm{K}_{2} \mathrm{O}$ rich. lightly sodic clastic sediments. } \\
\hline $768 \mathrm{C}-1 \mathrm{IR}-5,15-17$ & ICS & 68.06 & 0.75 & 13.39 & 7.85 & 3.64 & & 0.46 & 1.00 & 2.79 & 2.06 \\
\hline $768 C-29 R-4,13-16$ & ICS & 65.75 & 0.72 & 16.40 & 7.83 & 2.92 & & 0.65 & 1.26 & 3.17 & 1.29 \\
\hline $768 \mathrm{C}-1 \mathrm{R}-3,113-115$ & ICS & 63.35 & 0.81 & 16.85 & 8.69 & 3.24 & & 0.28 & 0.80 & 3.47 & 2.51 \\
\hline $768 \mathrm{~B}-28 \mathrm{X}-1,108-113$ & ICS & 61.87 & 0.86 & 18.73 & 8.60 & 3.13 & 0.54 & 0.36 & 0.57 & 3.85 & 1.48 \\
\hline $768 \mathrm{~B}-33 \mathrm{X}-2,130-134$ & ICS & 60.05 & 0.93 & 19.51 & 9.23 & 3.34 & & 0.72 & 0.89 & 4.05 & 1.29 \\
\hline $768 C-18 R-4,62-66$ & ICS & 59.64 & 1.00 & 19.37 & 9.72 & 3.88 & & 0.83 & 1.35 & 3.67 & 0.54 \\
\hline $768 \mathrm{C}-23 \mathrm{R}-1,92-94$ & ICS & 58.66 & 1.05 & 21.24 & 9.80 & 3.40 & & 0.43 & 1.12 & 4.30 & \\
\hline $768 \mathrm{C}-6 \mathrm{R}-2,20-23$ & ICS & 63.57 & 0.87 & 15.43 & 10.65 & 3.37 & & 0.67 & 0.99 & 2.73 & 1.78 \\
\hline $768 \mathrm{~B}-60 \mathrm{X}-2,100-103$ & TB & 62.06 & 0.90 & 16.98 & 10.16 & 2.41 & & 0.77 & 1.09 & 2.92 & 2.69 \\
\hline 768B-18H-1, 100-105 & $\mathrm{C}$ & 56.91 & 0.96 & 21.99 & 10.15 & 4.24 & & 0.79 & 1.66 & 3.31 & \\
\hline \multicolumn{12}{|l|}{$\mathrm{CaO}$ rich sediments } \\
\hline 767B-70X-5, 79-81 & HMP & 57.76 & 0.90 & 18.71 & 8.78 & 6.26 & & 1.92 & 2.17 & 2.29 & 1.20 \\
\hline $769 \mathrm{~B}-20 \mathrm{H}-6,31-35$ & HMP & 57.13 & 0.93 & 21.31 & 8.39 & 4.14 & & 2.54 & 1.48 & 3.35 & 0.72 \\
\hline $769 \mathrm{~B}-16 \mathrm{H}-4,31-33$ & HMP & 57.19 & 0.94 & 21.83 & 9.85 & 4.03 & & 1.60 & 1.31 & 3.24 & \\
\hline $767 \mathrm{~B}-35 \mathrm{X}-1,69-71$ & VCS & 57.88 & 0.93 & 19.18 & 8.97 & 2.51 & & 1.78 & 3.24 & 3.64 & 1.86 \\
\hline $767 \mathrm{~B}-54 \mathrm{X}-3,80-82$ & TB & 63.45 & 0.66 & 17.70 & 9.04 & 2.55 & & 1.11 & 1.22 & 2.56 & 1.72 \\
\hline $768 C-39 R-4,24-27$ & VT & 64.56 & 0.55 & 17.67 & 8.00 & 3.05 & & 2.34 & 1.59 & 1.69 & 0.55 \\
\hline $767 \mathrm{~B}-40 \mathrm{X}-3,134-136$ & TB & 58.35 & 1.11 & 19.23 & 9.79 & 3.84 & & 2.34 & 1.95 & 1.43 & 1.97 \\
\hline 767B-50X-3, 24-28 & HMP & 55.05 & 1.08 & 21.01 & 10.47 & 2.92 & & 4.20 & 1.31 & 2.08 & 1.88 \\
\hline $767 \mathrm{~B}-6 \mathrm{H}-1,20-25$ & VCS & 53.41 & 0.83 & 19.30 & 10.74 & 3.98 & & 5.81 & 2.18 & 2.40 & 1.34 \\
\hline $767 \mathrm{~B}-22 \mathrm{X}-1,18-23$ & VCS & 53.08 & 1.04 & 18.60 & 10.49 & 5.53 & & 5.64 & 2.50 & 1.80 & 1.33 \\
\hline $767 \mathrm{~B}-10 \mathrm{H}-5,95-97$ & VCS & 45.04 & 0.77 & 14.31 & 19.22 & 2.29 & 0.08 & 4.26 & 1.55 & 1.80 & 10.70 \\
\hline $768 \mathrm{C}-50 \mathrm{R}-3,55-57$ & VP & 59.21 & 0.78 & 14.50 & 11.75 & 2.83 & & 4.92 & 1.72 & 4.29 & \\
\hline
\end{tabular}

${ }^{1}$ Lith.: lithology; ICS: interbedded claystone/siltstone; TB: turbidite; HMP: hemipelagic claystone; VCS: volcanogenic claystone/siltstones;

VP: volcanic pyroclastite; VT: volcanic tuff; C: claystone

Table 7. Chemical classification of brown claystones and associated sediments from Leg 124.

\begin{tabular}{|c|c|c|c|c|c|c|c|c|c|c|c|c|}
\hline Core, section, & Lith. ${ }^{1}$ & $\mathrm{SiO}_{2}$ & $\mathrm{TiO}_{2}$ & $\mathrm{AL}_{2} \mathrm{O}_{3}$ & $\mathrm{Fe}_{2} \mathrm{O}_{3}$ & $\mathrm{MgO}$ & $\mathrm{MnO}$ & $\mathrm{CaO}$ & $\mathrm{Na}_{2} \mathrm{O}$ & $\mathrm{K}_{2} \mathrm{O}$ & $\mathrm{P}_{2} \mathrm{O}_{5}$ & $\mathrm{SO}_{3}$ \\
\hline \multicolumn{13}{|l|}{ interval $(\mathrm{cm})$} \\
\hline $769 C-2 R-5,133-136$ & $\mathrm{PC}$ & 56.64 & 0.66 & 16.79 & 12.00 & 5.69 & & 2.70 & 1.50 & 4.02 & & \\
\hline $768 \mathrm{C}-50 \mathrm{R}-1,2-4$ & VTB & 60.03 & 0.57 & 16.26 & 10.95 & 3.43 & & 3.17 & 1.87 & 3.37 & & 0.34 \\
\hline $767 \mathrm{~B}-78 \mathrm{X}-\mathrm{CC}, 10-13$ & PC & 59.34 & 0.98 & 18.48 & 10.58 & 2.49 & 1.14 & 1.81 & 1.39 & 3.45 & & 0.33 \\
\hline $767 C-7 R-2,67-70$ & PCSw & 58.93 & 1.01 & 22.91 & 5.88 & 3.61 & 2.41 & 2.21 & 0.99 & 2.05 & & \\
\hline 767B-75X-1, 127-129 & PC & 58.69 & 0.67 & 22.68 & 9.51 & 2.49 & 0.45 & 0.85 & 0.88 & 3.78 & & \\
\hline $767 \mathrm{~B}-75 \mathrm{X}-4,85-87$ & PC & 58.89 & 0.94 & 22.73 & 9.42 & 2.54 & & 1.11 & 0.96 & 3.41 & & \\
\hline 767B-74X-6, 61-63 & PC & 58.74 & 0.87 & 21.74 & 9.18 & 2.93 & 0.61 & 1.22 & 1.34 & 3.38 & & \\
\hline 767C-6R-1, 99-101 & PCT & 59.34 & 0.65 & 18.64 & 10.15 & 3.02 & 1.87 & 2.09 & 1.32 & 2.52 & 0.39 & \\
\hline $767 C-8 R-1,67-71$ & $\mathrm{PC}$ & 61.17 & 0.68 & 16.77 & 10.44 & 2.45 & 1.72 & 2.75 & 1.63 & 2.39 & & \\
\hline $767 C-8 R-1,94-96$ & $\mathrm{PC}$ & 60.52 & 0.85 & 17.74 & 10.75 & 2.98 & 0.94 & 2.50 & 1.40 & 2.32 & & \\
\hline $767 \mathrm{~B}-76 \mathrm{X}-4,72-74$ & $\mathrm{PC}$ & 59.02 & 0.73 & 17.53 & 12.30 & 2.99 & 0.72 & 2.61 & 1.48 & 2.15 & 0.46 & \\
\hline $767 C-7 R-2,67-70$ & $\mathrm{PCSr}$ & 58.24 & 0.87 & 23.23 & 10.53 & 2.32 & & 1.67 & 0.16 & 2.97 & & \\
\hline $767 \mathrm{C}-8 \mathrm{R}-1,34-36$ & $\mathrm{PC}$ & 61.67 & 0.58 & 17.08 & 9.55 & 2.62 & 1.57 & 2.85 & 1.77 & 2.00 & 0.30 & \\
\hline $767 \mathrm{C}-6 \mathrm{R}-3,46-48$ & PCT & 62.34 & 0.76 & 19.74 & 7.55 & 3.07 & & 3.32 & 2.04 & 1.19 & & \\
\hline $767 C-8 R-1,73-75$ & $\mathrm{PC}$ & 61.56 & 1.02 & 19.69 & 6.55 & 4.00 & 0.67 & 3.00 & 1.68 & 1.02 & 0.52 & 0.29 \\
\hline $767 C-6 R-1,15-17$ & PC & 61.95 & 0.68 & 20.58 & 6.61 & 4.50 & 0.46 & 2.64 & 1.60 & 0.98 & & \\
\hline 767B-78X-1, 71-73 & $\mathrm{PC}$ & 61.37 & 0.90 & 19.98 & 7.58 & 3.75 & 0.71 & 3.27 & 1.24 & 0.97 & & 0.22 \\
\hline 767C-7R-CC, $6-8$ & $\mathrm{PC}$ & 60.80 & 0.96 & 20.41 & 7.54 & 3.52 & & 3.37 & 2.57 & 0.85 & & \\
\hline
\end{tabular}

${ }^{1}$ Lith.: lithology; PC: pelagic claystone; VTB: volcanic tuff turbidite; PCS: pelagic claystone/siltstone; PCT: pelagic claystone and tuff.w : white; $r$ : red.

ments. Clinoptilolite and heulandite have been reported replacing volcanic glass matrix and volcanic rock fragments in sandstones and volcanic arenites from back-arc basins of the western Pacific (Lee and Klein, 1986). The lithology and the depth are apparently two factors that control the crystallization of both zeolites.
Pore waters of clinoptilolite-bearing sediments have, on average, a higher content of $\mathrm{SiO}_{2}$ than is found in the waters of phillipsite-bearing sediments (Hay, 1966). High silica activity favors clinoptilolite over phillipsite (Boles and Wise, 1977). In Leg 124 the silica concentration in pore fluids, below $300 \mathrm{~m}$, is the same regardless of the zeolite. 

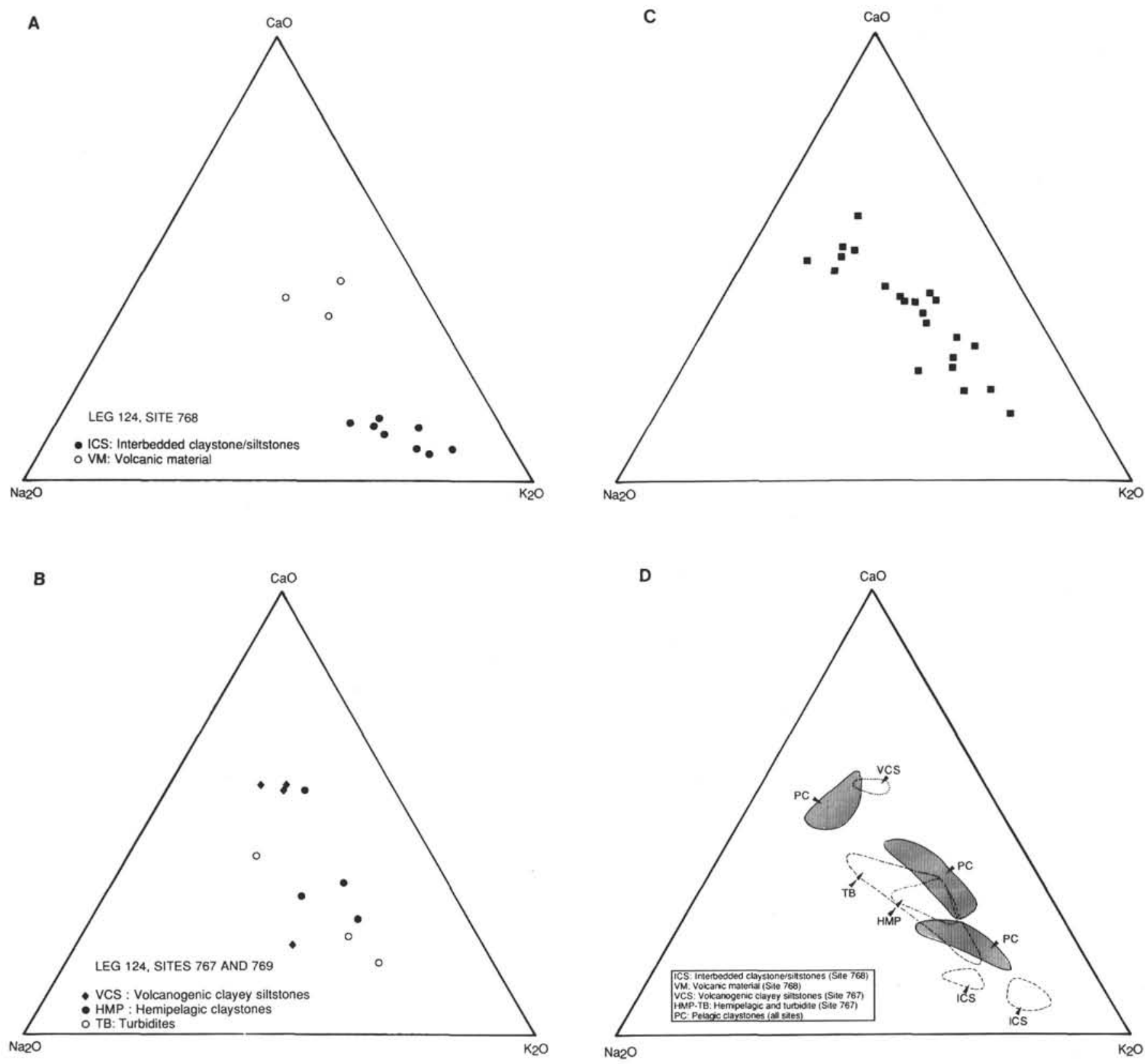

Figure 14. $\mathrm{CaO} / \mathrm{Na}_{2} \mathrm{O} / \mathrm{K}_{2} \mathrm{O}$ projection of bulk rocks compositions. A: Site 768; B: Site 767 and 769; C: Brown claystones; D: all samples.

Zeolites are also suspected when the chemical analyses of the fine-fractions $(2 \mu \mathrm{m})$ are rich in sodium and silicon, and low in aluminum. This argument, if correct, extends considerably the occurrences of zeolites in the sedimentary sequence. This mineral development may in part explain the silicon decrease in the pore fluids.

\section{Clay Minerals}

The diagenesis of clay minerals is subtle but real, and the evolution depends on the nature of the mineralogical heritage.

\section{Magnesium-rich Smectite}

The clay fraction, rich in smectite and less contaminated by the terrigenous influx are rich in magnesium and silicon, and either calcium (Site 767) or sodium (Site 768). On the other hand, clay fractions rich in mica, kaolinite, and disordered clay minerals, are enriched in aluminum and potassium, and depleted in silica.
The magnesian and silicic clay fractions observed in various lithologies are considered to be indicators of diagenetic crystallization. The magnesium and silicon enrichment of the clay-size fraction coincides with the drop in magnesium (Fig. 17) and silicon concentrations in the pore fluids. The low abundance of clay minerals at the top of the holes may explain the higher $\mathrm{Mg}$ - content of the pore fluids. At the bottom, the concentration is usually explained by the alteration reactions occurring in the Layer 2 basalt (Gieskes and Lawrence, 1981).

The higher magnesian concentration in the clay fraction at Site 767 (Celebes Sea) is possibly enhanced by the fixation of iron in the neogenetic glauconite. This may be an example of element partitioning between two diagenetic minerals. The lack of glauconite at Site 768 may correspond to unfavorable environmental conditions of formation. Another possibility is that at Site 767, the iron concentration in the pore fluids is 
Table 8. Chemical composition of the clay-size fractions $(2 \mu \mathrm{m}, 35 \mu \mathrm{m})$ of some sediments from Leg 124.

\begin{tabular}{|c|c|c|c|c|c|c|c|c|c|c|c|c|c|c|}
\hline $\begin{array}{l}\text { Core, section } \\
\text { interval }(\mathrm{cm})\end{array}$ & Lith $^{1}$ & $\mathrm{~m}^{2}$ & $\mathrm{SiO}_{2}$ & $\mathrm{TiO}_{2}$ & $\mathrm{Al}_{2} \mathrm{O}_{3}$ & $\mathrm{Fe}_{2} \mathrm{O}_{3}$ & $\mathrm{MgO}$ & $\mathrm{MnO}$ & $\mathrm{CaO}$ & $\mathrm{Na}_{2} \mathrm{O}$ & $\mathrm{K}_{2} \mathrm{O}$ & $\mathrm{P}_{2} \mathrm{O}_{5}$ & $\mathrm{SO}_{3}$ & a \\
\hline \multicolumn{15}{|l|}{$\begin{array}{l}\text { FRACTION }<2-\text { mm. } \\
\text { Site } 767 \text { (Celebes Sea) }\end{array}$} \\
\hline B- $6 \mathrm{H}-1,20-25$ & vCS & 4 & 58.53 & 1.01 & 19.34 & 10.43 & 5.86 & & 1.34 & 1.00 & 1.13 & & 1.36 & \\
\hline B- $10 \mathrm{H}-5,95-97$ & VCS & 3 & 54.33 & 0.80 & 19.86 & 15.06 & 4.50 & & 1.95 & & 1.95 & 0.20 & 1.28 & 0.07 \\
\hline B- $22 X-1,18-23$ & VCS & 3 & 59.04 & 0.79 & 18.43 & 10.51 & 7.40 & & 1.80 & 0.58 & 1.23 & 0.17 & & 0.05 \\
\hline B- $35 X-1,69-71$ & VCS & 3 & 59.43 & 1.08 & 19.75 & 9.87 & 6.19 & & 1.94 & & 0.99 & 0.67 & 0.08 & \\
\hline B- $40 X-3,134-136$ & $\mathrm{C}$ & 3 & 63.16 & 0.70 & 20.58 & 7.05 & 5.01 & & 2.19 & & 0.95 & & 0.36 & \\
\hline B- 54 X- $3,80-82$ & $\mathrm{~TB}$ & 3 & 56.91 & 0.44 & 26.07 & 7.91 & 3.71 & & 1.15 & 0.04 & 3.38 & & 0.40 & \\
\hline B- $60 \times-2,100-103$ & $\mathrm{~TB}$ & 4 & 60.85 & 0.59 & 22.54 & 7.70 & 3.96 & & 0.21 & 0.28 & 2.91 & 0.28 & 0.62 & 0.05 \\
\hline B-70X-5, 79-81 & HMP & 4 & 56.39 & 0.63 & 20.68 & 6.05 & 8.49 & 0.10 & 1.32 & 2.31 & 1.68 & 0.88 & 1.47 & \\
\hline B-75X-1, $127-129$ & $\mathrm{PC}$ & 3 & 52.25 & 0.59 & 24.82 & 11.74 & 2.87 & & 0.66 & 2.11 & 3.15 & & 1.82 & \\
\hline $\mathrm{B}-78 \mathrm{X}-\mathrm{CC}, \mathrm{I0}-13$ & $\mathrm{PC}$ & 3 & 57.14 & 0.58 & 21.11 & 10.53 & 4.37 & 1.51 & 0.23 & & 3.33 & & 0.63 & 0.56 \\
\hline C-8R-1, 67-71 & $\mathrm{PC}$ & 4 & 58.08 & 0.45 & 16.54 & 11.27 & 4.59 & 1.86 & 0.54 & 2.01 & 3.25 & 0.29 & 0.94 & 0.20 \\
\hline \multicolumn{15}{|l|}{ Site 768 (Sulu Sea) } \\
\hline B- $28 X-1,108-113$ & ICS & 3 & 57.71 & 0.44 & 24.70 & 7.57 & 4.39 & & 0.88 & & 4.23 & & 0.08 & \\
\hline C-1R-3, 113-115 & ICS & 3 & 56.34 & 0.47 & 25.24 & 8.58 & 4.31 & & $\begin{array}{l}0.11 \\
1.11\end{array}$ & & 3.95 & & & \\
\hline C- $6 \mathrm{R}-2,20-23$ & ICS & 3 & 56.88 & 0.69 & 21.95 & 9.86 & 5.46 & & 1.53 & 0.35 & 2.95 & & 0.21 & 0.12 \\
\hline C-23R-1, 92-94 & ICS & 3 & 53.91 & 0.59 & 22.93 & 8.91 & 3.88 & & 0.37 & 2.58 & 3.93 & & 2.85 & 0.04 \\
\hline C- $29 R-4,13-16$ & ICS & 3 & 54.44 & 0.44 & 25.69 & 8.72 & 4.22 & 0.13 & 0.98 & 0.18 & 5.04 & & 0.15 & \\
\hline C- $39 R-4,24-27$ & VT & 3 & 62.81 & 0.40 & 18.31 & 7.06 & 4.91 & & 0.59 & 2.99 & 0.62 & & 2.30 & \\
\hline C-49R-1, 52-54 & CVT & 3 & 57.71 & 0.74 & 20.42 & 12.15 & 5.66 & & 1.44 & & 1.63 & & 0.39 & 0.07 \\
\hline C- 50 R-1, $2-4$ & VT & 3 & 58.81 & 0.55 & 18.19 & 9.91 & 4.43 & 0.25 & 0.37 & 2.79 & 2.90 & & 1.70 & 0.10 \\
\hline C- $-50 \mathrm{R}-3,55-57$ & VP & 3 & 54.79 & 0.80 & 10.76 & 13.48 & 4.68 & 0.28 & 0.52 & 2.51 & 7.22 & & 4.87 & 0.10 \\
\hline Site 769 (Cagayan Block) & & & & & & & & & & & & & & \\
\hline B- $16 \mathrm{H}-4,31-33$ & HMP & 3 & 54.98 & 0.53 & 24.03 & 10.02 & 4.51 & & 0.36 & 0.79 & 3.38 & 1.41 & & \\
\hline B-20H-6, $31-35$ & HMP & 3 & 58.71 & 0.36 & 21.87 & 9.33 & 4.86 & & 1.31 & 0.23 & 2.82 & 0.45 & 0.07 & \\
\hline C- $2 R-5,133-136$ & PC & 3 & 57.94 & 0.55 & 16.22 & 8.96 & 6.98 & & 0.41 & 3.61 & 2.23 & 3.03 & 0.07 & \\
\hline \multicolumn{15}{|l|}{$\begin{array}{l}\text { FRACTION }<35-\mathrm{mm} \\
\text { Site } 767 \text { (Celebes Sea) }\end{array}$} \\
\hline C- 7 R- $2,67-70$ & PCS & 1 & 60.76 & 1.16 & 21.49 & 7.27 & 2.28 & 0.67 & 1.69 & 1.39 & 3.02 & & & 0.28 \\
\hline C-9R-02, 88-94 & $\mathrm{PC}$ & $i$ & 64.53 & 1.03 & 22.81 & 2.30 & 4.26 & 0.40 & 2.51 & 1.87 & & & & 0.30 \\
\hline
\end{tabular}

${ }^{1}$ Lith: Lithology; VCS: volcanogenic clayey silstone; C: claystone; HMP: hemipelagic claystone; TB: turbidite; HMP: hemipelagic ; PC: pelagic claystone; ICS: interbedded claystone/siltstone; VT: volcanic tuff; CVT: claystone with volcanic tuff; VP: volcanic pelagic.

2 number of analyses in the average.

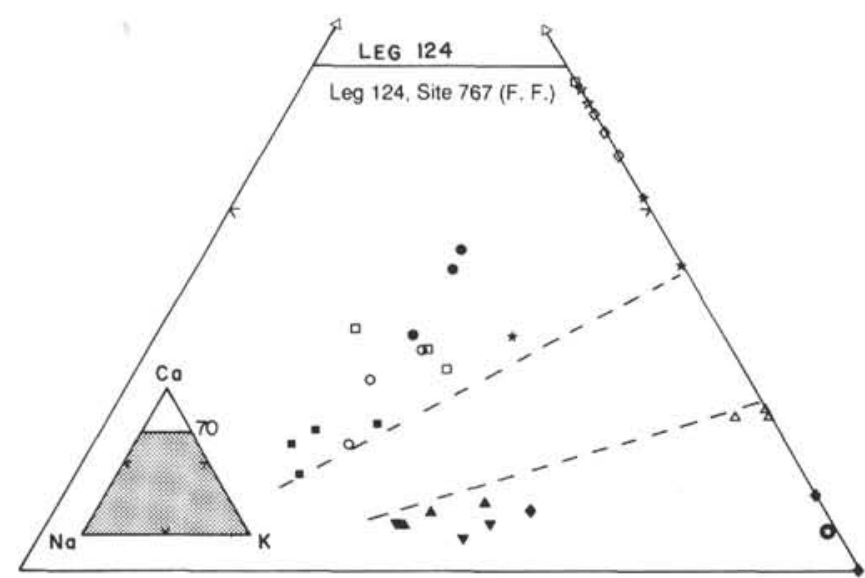

Figure 15. Alkalines and calcium contents of the fraction $2 \mu \mathrm{m}$ of various sediments from Leg 124, Site 767 (each symbol represent a different bed).

increased by the incipient alteration of volcanic ferromagnesian minerals scattered through the sedimentary sequence.

Although some contamination by a small amount of plagioclase or zeolite cannot be excluded, the smectite appears to be calcic or sodic. An indirect argument, at least at Site 767 , is that in glauconitic sediments, the potassium should enter that mineral. At Site 767 the diagenetic clay

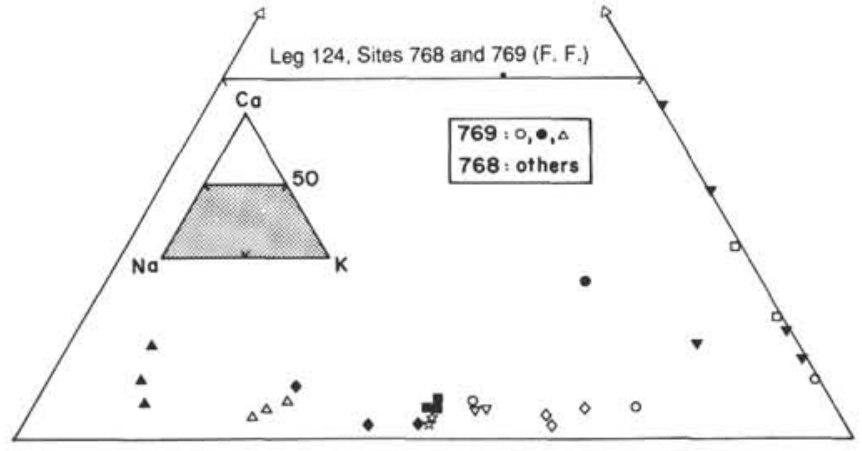

Figure 16. Alkalines and calcium contents of the fractions $2 \mu \mathrm{m}$ of various sediments from Leg 124, Sites 768 and 769 (each symbol represents a different bed) of various sediments from Leg 124.

association may be: $\mathrm{Ca}$ or $\mathrm{Ca}-\mathrm{Na}, \mathrm{Mg}-\mathrm{Si}$-rich smectite + $\mathrm{K}-\mathrm{A} 1, \mathrm{Fe}$ Glauconite.

\section{Degradation of the Disordered Interstratified Clay Minerals}

In the sediments rich in disordered interstratified clay minerals and in micas, the diagenesis of the clay fraction is more difficult to define. The interpretation of the $17-\AA$ peak is ambiguous as a low saddle/peak ratio may signify either a high proportion of pure smectite in the mixture of smectite- randomly interstratified minerals, or a higher proportion of smectite layers in the random interstratified clay minerals. Whatever the physical state of the smectite component, its chemi- 

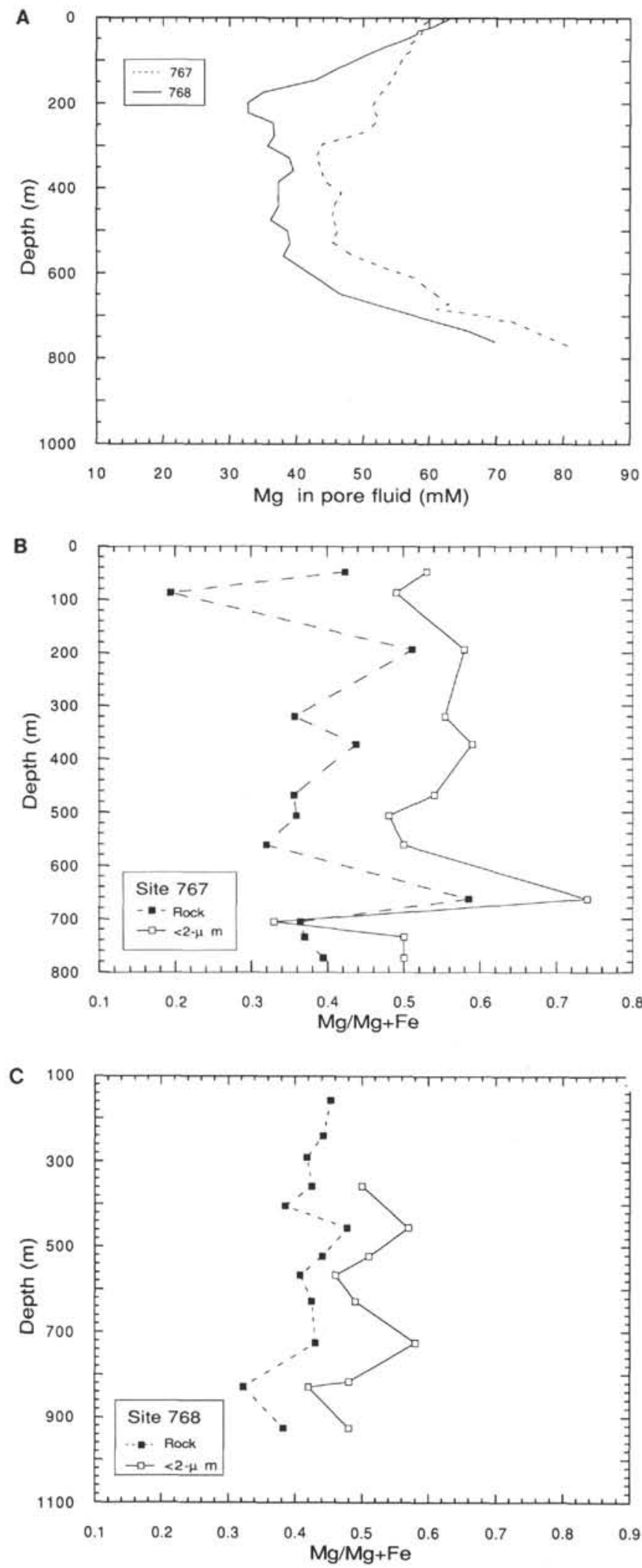

Figure 17. A. Depth variations of the pore fluid magnesium content (from Rangin, Silver, von Breymann, et al., 1990), and the $\mathrm{Fe} / \mathrm{Mg}$ ratios in the rock and the clay-size fraction $(2 \mu \mathrm{m})$ at B. Site 767 and C. Site 768 (Leg 124).
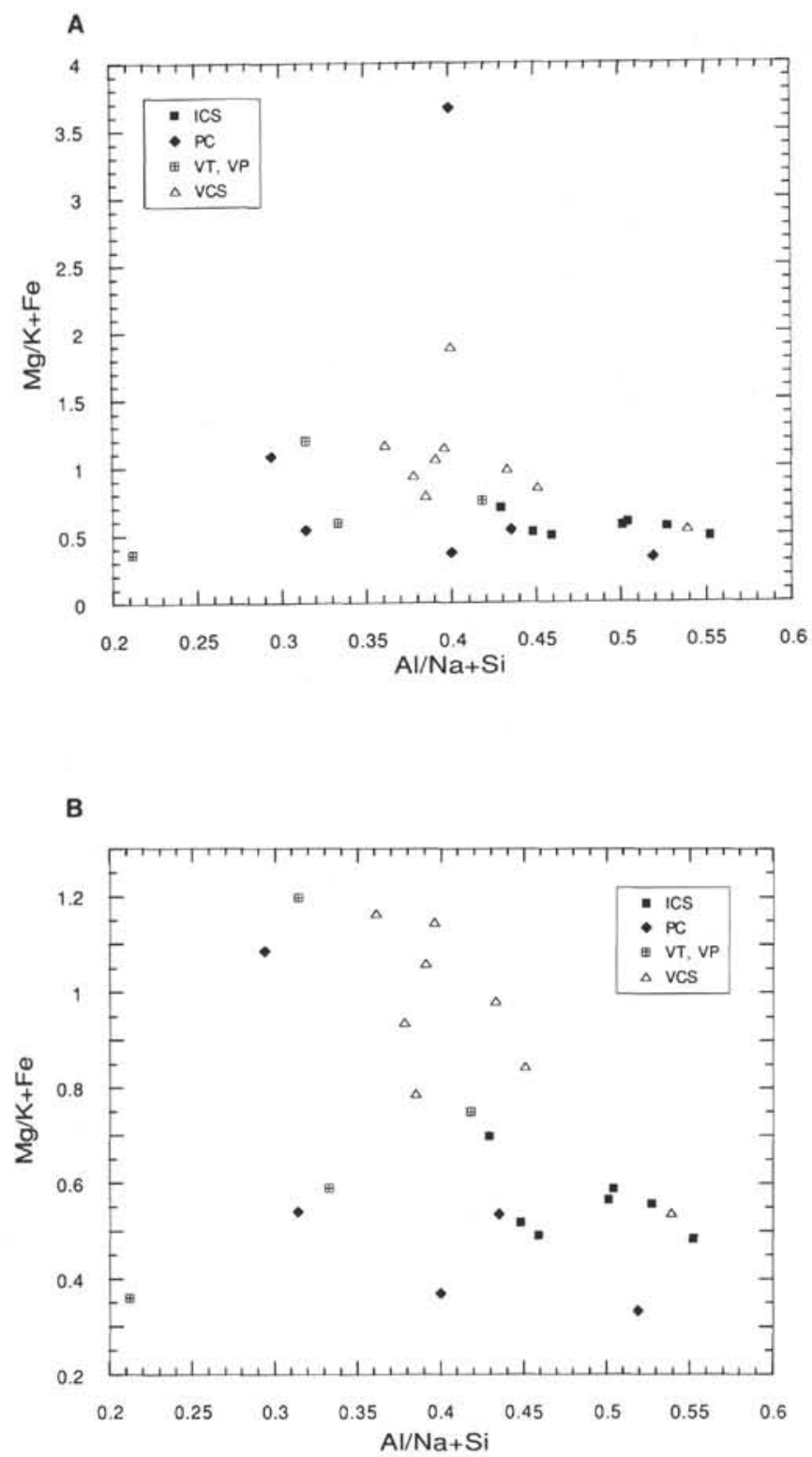

Figure $18 . \mathrm{Mg} / \mathrm{K}+\mathrm{Fe}$ vs. $\mathrm{Al} / \mathrm{Na}+\mathrm{Si}$ projections of the chemical composition of the fine-fraction from various sediments from Leg 124. A. All data. B. Part of A with an expanded scale.

cal characteristics are hidden by the heritage of the random mixed-layer clay minerals.

The random mixed-layer clay minerals arrive in the sedimentary basins at different stages of evolution. The nature of diagenesis of clay minerals upon contact with seawater is a controversial subject (Hathaway, 1979). Detrital clay minerals are unstable in the marine environment, as are other detrital minerals, but the structure and granulometry of clays make their degradation more rapid. One argument in favor of their alteration is the increase in the alkalinity of the pore fluids at Site 767 and Site 768 at intermediate depth (Fig. 20). The major increase occurs at Site 768 where the disordered interstratified clay minerals are more abundant and more "illitic." The dissolution of feldspar may be a complementary factor.

A second argument comes from the comparison between the aluminum-rich fine fractions and the magnesium-rich fine-fractions (Table 9). The mica content in the $\mathrm{Mg}$-rich 
Table 9. Chemical classification of the composition of the clay-size fractions ( $<2 \mu \mathrm{m},<35 \mu \mathrm{m}$ ) of the sediments from Leg 124 (structural formula on a $22+$ cations basis)

\begin{tabular}{|c|c|c|c|c|c|c|c|c|c|c|c|c|c|c|c|c|}
\hline $\begin{array}{l}\text { Core section, } \\
\text { interval }(\mathrm{cm})\end{array}$ & Lith. & $\mathbf{S}$ & $\mathrm{Al}^{\mathrm{IN}}$ & $\mathrm{Al}^{\mathrm{VI}}$ & $\mathrm{Ti}_{\mathrm{i}}$ & $\mathrm{Fe}$ & $\mathrm{Mg}$ & Mn & a & $\mathrm{Na}$ & K & $\mathrm{Al}^{\mathrm{l}}$ & $9 \mathrm{Cl}$ & $\% \mathrm{M}$ & $\% \mathrm{~K}$ & \% \\
\hline \multicolumn{17}{|l|}{ Potassium-000r fine fractions } \\
\hline $767 \mathrm{~B}-40 \mathrm{X}-3,134-136$ & C & 3.777 & 0.223 & 1.274 & 0.032 & 0.327 & 0.461 & & 0.145 & & 0.075 & 1.497 & 92 & & 8 & 26 \\
\hline 767B-35X-1, 69-71 & ves & 3.663 & 0.337 & 1.097 & 0.050 & 0.458 & 0.569 & & 0.129 & & 0.078 & 1.434 & 95 & & 5 & 25 \\
\hline 767B-10H-5, $95-97$ & ves & 3.769 & 0.231 & 1.253 & 0.038 & 0.391 & 0.378 & & 0.142 & & 0.088 & 1.484 & 59 & 22 & 19 & 42 \\
\hline $768 \mathrm{C}-39 \mathrm{R}-4,24-27$ & vT & 3.886 & 0.114 & 1.221 & 0.018 & 0.329 & 0.453 & & 0.039 & 0.359 & 0.049 & 1.416 & 95 & & 5 & 8 \\
\hline $767 \mathrm{~B}-6 \mathrm{H}-1,20-25$ & ves & 3.657 & 0.343 & 1.073 & 0.047 & 0.488 & 0.542 & & 0.090 & 0.121 & 0.089 & 1.406 & 65 & 22 & 13 & \\
\hline $767 \mathrm{~B}-22 \mathrm{X}-1,18-23$ & ves & 3.648 & 0.352 & 0.990 & 0.036 & 0.489 & 0.682 & & 0.120 & 0.070 & 0.096 & 1.342 & 93 & 15 & 12 & 33 \\
\hline \multicolumn{17}{|l|}{ Aluminum-rich fine fractions } \\
\hline 767B-54X-3, 80-82 & TB & 3.508 & 0.492 & 1.402 & 0.020 & 0.367 & 0.341 & & 0.076 & 0.005 & 0.266 & 1.894 & 70 & 20 & 10 & 30 \\
\hline $768 \mathrm{~B}-1 \mathrm{R}-3,113-115$ & ICS & 3.485 & 0.515 & 1.325 & 0.022 & 0.399 & 0.397 & & 0.073 & & 0.312 & 1.840 & 35 & 37 & 28 & \\
\hline $768 \mathrm{~B}-28 \mathrm{X}-1,108-113$ & ICS & 3.557 & 0.443 & 1.350 & 0.020 & 0.351 & 0.403 & & 0.058 & & 0.333 & 1.794 & 54 & 36 & 10 & 42 \\
\hline $768 C-29 R-4,13-16$ & ICS & 3.410 & 0.590 & 1.306 & 0.022 & 0.411 & 0.394 & 0.007 & 0.066 & 0.021 & 0.402 & 1.896 & 40 & 42 & 17 & \\
\hline 767B-75X-1, $127-129$ & PC & 3.350 & 0.650 & 1.226 & 0.028 & 0.566 & 0.274 & & 0.046 & 0.263 & 0.257 & 1.876 & 70 & 17 & 13 & 34 \\
\hline $769 \mathrm{~B}-16 \mathrm{H}-4,31-33$ & HMP & 3.464 & 0.536 & 1.249 & 0.025 & 0.475 & 0.423 & & 0.024 & 0.096 & 0.272 & 1.784 & 61 & 22 & 17 & 40 \\
\hline $768 \mathrm{C}-23 \mathrm{R}-1,92-94$ & $\mathrm{KCS}$ & 3.478 & 0.522 & 1.222 & 0.029 & 0.433 & 0.373 & & 0.025 & 0.323 & 0.323 & 1.744 & 55 & 29 & 15 & 49 \\
\hline $768 \mathrm{C}-18 \mathrm{R}-4,62-66$ & ICS & 3.465 & 0.535 & 1.268 & 0.027 & 0.366 & 0.385 & & 0.033 & 0.310 & 0.377 & 1.804 & 48 & 36 & 16 & 56 \\
\hline \multicolumn{17}{|l|}{ Aluminum-poer fine fractions } \\
\hline 769C-2R-5, 133-136 & PC & 3.722 & 0.278 & 0.949 & 0.027 & 0.433 & 0.668 & & 0.028 & 0.450 & 0.182 & 1.227 & 91 & 7 & 3 & 15 \\
\hline $767 \mathrm{C}-8 \mathrm{R}-1,67-71$ & PC & 3.719 & 0.281 & 0.967 & 0.022 & 0.543 & 0.438 & 0.101 & 0.037 & 0.249 & 0.266 & 1.248 & 90 & 10 & & 19 \\
\hline $768 \mathrm{C}-50 \mathrm{R}-3,55-57$ & PV & 3.771 & 0.229 & 0.645 & 0.042 & 0.698 & 0.479 & 0.016 & 0.038 & 0.334 & 0.634 & 0.873 & 32 & 61 & 7 & \\
\hline \multicolumn{17}{|c|}{ Fine fractions with mixed-characters } \\
\hline $767 \mathrm{~B}-50 \mathrm{X}-3,24-28$ & HMP & 3.659 & 0.342 & 1.317 & 0.039 & 0.352 & 0.405 & & 0.111 & 0.022 & 0.127 & 1.659 & 68 & 8 & 14 & 23 \\
\hline $767 \mathrm{~B}-70 \mathrm{X}-5,79-81$ & HMP & 3.552 & 0.448 & 1.088 & 0.030 & 0.287 & 0.798 & 0.005 & 0.089 & 0.282 & 0.135 & 1.536 & 78 & 13 & 9 & 26 \\
\hline $769 \mathrm{~B}-20 \mathrm{H}-6,31-35$ & HMP & 3.632 & 0.368 & 1.227 & 0.025 & 0.434 & 0.447 & & 0.087 & 0.028 & 0.222 & 1.594 & 53 & 29 & 18 & 51 \\
\hline $767 \mathrm{~B}-60 \mathrm{X}-2,100-103$ & TB & 3.731 & 0.269 & 1.360 & 0.027 & 0.355 & 0.362 & & 0.018 & 0.034 & 0.228 & 1.629 & 56 & 27 & 17 & 44 \\
\hline $768 \mathrm{C}-6 \mathrm{R}-2,20-23$ & ICS & 3.541 & 0.459 & 1.151 & 0.032 & 0.462 & 0.506 & & 0.102 & 0.064 & 0.234 & 1.608 & 66 & 21 & 12 & 37 \\
\hline $768 \mathrm{C}-11 \mathrm{R}-5,15-17$ & ICS & 3.488 & 0.512 & 1.138 & 0.029 & 0.391 & 0.519 & & 0.035 & 0.356 & 0.350 & 1.651 & 59 & 27 & 13 & 46 \\
\hline $768 C-49 R-1,52-54$ & VT & 3.575 & 0.425 & 1.071 & 0.035 & 0.568 & 0.524 & & 0.095 & & 0.129 & 1.496 & & & & \\
\hline $768 \mathrm{C}-50 \mathrm{R}-1,2-4$ & VTB & 3.728 & 0.272 & 1.086 & 0.026 & 0.473 & 0.418 & 0.014 & 0.025 & 0.343 & 0.235 & 1.358 & 91 & 9 & & 20 \\
\hline 767B-78X-CC, $10-13$ & PC & 3.601 & 0.399 & 1.170 & 0.027 & 0.499 & 0.411 & 0.081 & 0.016 & & 0.268 & 1.568 & 82 & 13 & 5 & 20 \\
\hline \multicolumn{17}{|l|}{ Eractions $<35-\mathrm{mm}$} \\
\hline $767 \mathrm{C}-9 \mathrm{R} 2,88-93$ & $\mathrm{PCw}$ & 3.848 & 0.152 & 1.451 & 0.046 & 0.103 & 0.378 & 0.020 & 0.160 & 0.186 & & 1.603 & & & & \\
\hline $767 \mathrm{C}-6 \mathrm{R}-1,15-17$ & $\mathrm{PCr}$ & 3.749 & 0.251 & 1.312 & 0.054 & 0.337 & 0.210 & 0.035 & 0.112 & 0.137 & 0.237 & 1.563 & & & & \\
\hline
\end{tabular}

peak. Lith: lithology; TB: turbidite; VCS: volcanogenic claystones/siltstone; VT: volcanic tuff; ICS: interbeded claystone/siltstone; PC: pelagic claystones; PV: pyroclastic material; HMP: hemipelagic claystones; $\mathrm{C}$ : claystones 


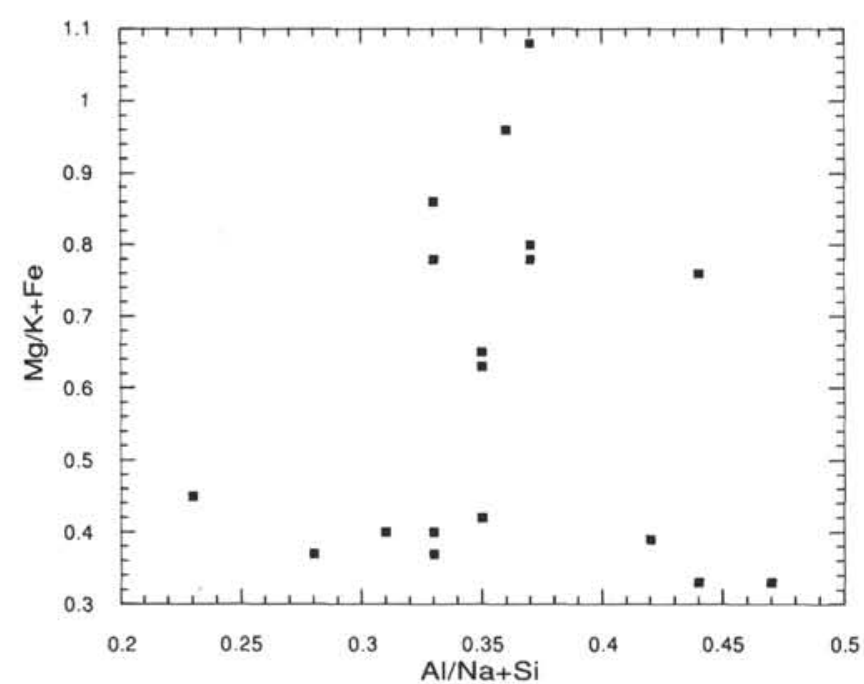

Figure 19. $\mathrm{Mg} / \mathrm{K}+\mathrm{Fe}$ vs. $\mathrm{Al} / \mathrm{Na}+\mathrm{Si}$ projections of the chemical compositions of the fine-fractions from brown claystones (Leg 124).

sediments is lower than in the aluminum-rich group, but the "apparent illite content" is not very different. The magnesian character is thus associated with the randomly interstratified clay minerals, whereas the micas are more iron-rich. Consequently, the disordered interstratified clay minerals of detrital origin are subjected to diagenetic evolution and contribute to the reduction of magnesium in the pore fluids. Their chemistry reflects an evolution toward equilibrium with the pore fluid. They no longer represent the original detrital fraction. This explains also the relative simplicity of the $17-\AA \AA$ peak in spite of the continental origin of the material, which would be expected to be more heterogeneous in nature.

\section{Smectites in the Pelagic Formations}

\section{Brown Claystones}

In the brown claystones, the detrital contamination by randomly interstratified clay minerals and micas is minor compared to all the other detrital sediments. In one exception, the composition is iron-rich and some contamination by iron oxyhydroxides is suspected. However, the clay fraction is as magnesiumrich as the other detrital sediments. Furthermore, kaolinite is absent or rare and zeolites are common. The high iron and magnesium contents of the smectite may reflect a relative deficit in aluminum in these rocks, and a possible competition for that element between the zeolites and the smectite. Significantly, the only clay fraction in which magnesium is higher than iron is also the most rich in zeolites (Table 8).

\section{White Interbed Layers}

To the opposite of the previous observations, aluminous smectite is present in whitish interbeds intercalated in the brown claystone formations. The dioctahedral character is confirmed by a low d $(060)=1.495$ (Sample 124-767C- 9R-2, $88-93 \mathrm{~cm}$ ). Devoid of potassium and rich in magnesium and silicon, this smectite is of a beidellite type (Güven, 1988) and is quite different from the iron-rich smectite of the brown claystones (Fig. 21). The white bed does not represent normal marine sedimentation. It differs from the brown claystones in the concentration of transition elements and by high concentrations of vanadium and zirconium (Table 10), and is probably an altered volcanic bed. Aluminous smectites are produced by the alteration of oceanic basalts at low temperature, $\left(50^{\circ} \mathrm{C}\right)$, and in ocean crust older than $50 \mathrm{~m} . \mathrm{y}$. (Scheidegger and
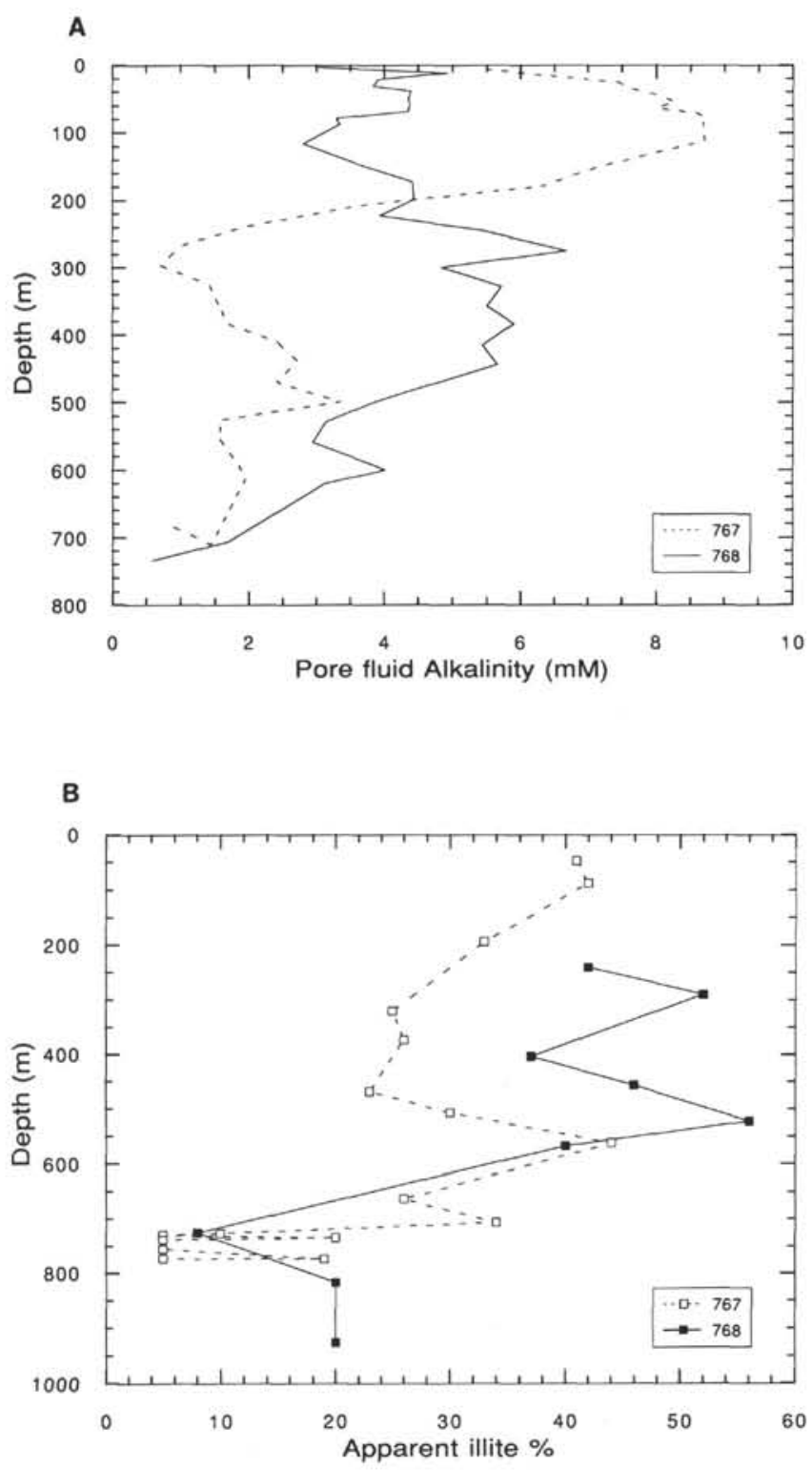

Figure 20. A. Depth variations of the pore fluids alkalinity (from Rangin, Silver, von Breymann, et al., 1990), at Site 767 and 768, and B. "apparent illite content" of the clay-size fraction of the sediments.

Stakes, 1980; Mevel, 1980; Alt and Honnorez, 1984). White dioctahedral $\mathrm{Al}$ - rich, $\mathrm{Mg}$ - and $\mathrm{Fe}$-poor smectites are also known in high thermal alteration of tholeiitic basaltic glass and calcic plagioclases, and in hydrothermal vents on the crest of the East Pacific Ridge at $21^{\circ} \mathrm{N}$ (Haymon and Kastner, 1986).

\section{Diagenesis and the Heat Flow}

\section{Absence of Thermal Effect}

The smectite stability in the brown claystones, in the deepest samples at Site 767, and in volcanic tuffs of Unit III at Site 768, excludes any intense thermal event. The transformation of smectite to illite is also not observed in the other detrital sediments. A few isotopic data confirm the low temperature at Site $767\left(\delta^{18} \mathrm{O}\right.$ (SMOW) $=28 \%$ for Sample 124-767C-6R-1, 15-17 cm; $\delta^{18} \mathrm{O}(\mathrm{SMOW})=25.7 \%$ for Sample 124-767C-9R-2, 88-93 cm). Assuming that the water with 


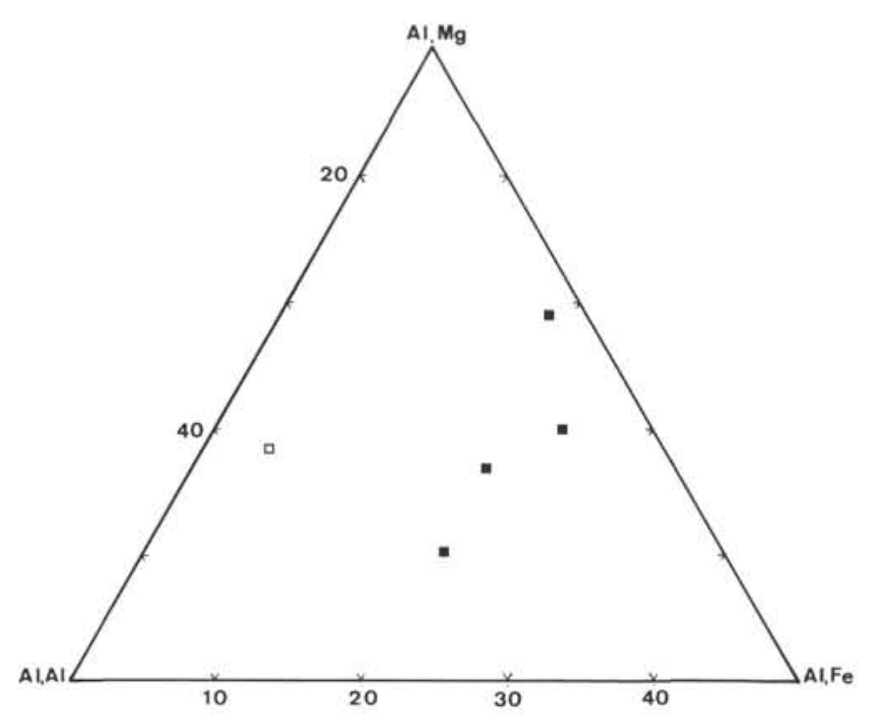

Figure 21. Projection of the chemical compositions of smectite-rich fractions in the $\mathrm{Al} / \mathrm{Fe} / \mathrm{Mg}$ triangle. Solid squares: brown claystones. Open square: whitish interbed (Sample 124-767C-9R-2, 88-93 cm).

Table 10. Trace-element compositions (ppm) of some brown claystones and associated white layers from Leg 124.

\begin{tabular}{crrr}
\hline Samples $^{1}$ & A & B & C \\
\hline V & 186 & 120 & \\
Gr & 30 & 17 & 348 \\
$\mathrm{Mn}$ & 3617 & 3638 & 0 \\
$\mathrm{Co}$ & 32 & 32 & 1470 \\
$\mathrm{~N}$ & 60 & 55 & 91 \\
$\mathrm{Cu}$ & 99 & 114 & 95 \\
$\mathrm{Zn}$ & 115 & 130 & 173 \\
$\mathrm{Li}$ & 82 & 58 & 119 \\
$\mathrm{Sr}$ & 102 & 148 & 25 \\
$\mathrm{Ba}$ & 199 & 407 & 120 \\
$\mathrm{Rb}$ & 144 & 95 & 324 \\
$\mathrm{Zr}$ & 151 & 111 & 8 \\
& & & 282 \\
\hline
\end{tabular}

${ }^{1} \mathrm{~A}: 124-767 \mathrm{~B}-75 \mathrm{X}-4,85-87$; B: $124-767 \mathrm{~B}-76 \mathrm{X}-4,72-74$; C: $124-767 \mathrm{C}-$ 9R-2, 88-93.

which the smectite equilibrated had an oxygen isotopic value of $\delta^{18} \mathrm{O}=0 \%$, and using the smectite-water oxygen isotopic fractionation of Yeh and Savin (1976), the isotopic equilibration temperature for smectites are in the range of $10^{\circ}-20^{\circ} \mathrm{C}$.

\section{Significance of the Ordered Mixed-layer Clay Minerals}

The ordered di- and trioctahedral clay minerals observed in volcanic pyroclastics (Unit IV) at Site 768 (Sulu Sea) seem out of place when one considers all the results. Their presence means either a late magmatic recrystallization in a hot tephra, or a local circulation of warm fluids along some fault system. Microfaults, conjugate fractures, and normal faults sealed with silica were observed between the Cores 124-768C-49R and $124-768 \mathrm{C}-59 \mathrm{R}$, the interval in which the pyroclastic unit is located. For these reasons, the second hypothesis is preferred. Unit IV is at the top of a sedimentary sequence that infills a half-graben structure as seen from the seismic refraction profiles. Hydrothermal circulation of water or heat flow from basement may be related to the rifting process

The ordered clay minerals constitute minor and sporadic phases in the other detrital sediments, younger in age than the pyroclastic unit: Miocene to late Miocene in Unit II at Site 768, Pliocene in Unit IIA at Site 769. These rare occurrences may be considered to be some indication that the heat flow has affected the entire sedimentary sequence. However, this interpretation is inconsistent with the presence of pure smectite associated with clinoptilolite in a tuff layer at the base of Unit III. Another interpretation is that the ordered interstratified clay minerals represent the detrital product of this unit at Site 768 , or a lateral equivalent. An unconformity or a hiatus within Unit III has been proposed from seismic records and paleontological observations of reworked Zone NN5 nannofossils in the Zone NN8 horizons supports this idea. If this interpretation is correct, the ordered clay-minerals developed in the volcanic unit before the middle Miocene. As the post-rift sediments escaped the high thermal effect, the gradient should have declined rapidly. In the Cagayan block, the ordered clay-minerals found in the Pliocene sediments may be derived from the Sulu source. However, a thick volcanic unit is present below the Cagayan block brown claystones and it would be interesting to know if the ordered clay minerals developed there too. In the Celebes Sea, no ordered clay minerals were suspected.

\section{CONCLUSION}

The mineralogical and chemical studies of the rocks and their fine-fractions ( $2 \mu \mathrm{m}$ ) allow one to recognize two main detrital contributions in the sedimentary sequences of the Celebes and Sulu Basins, and the Cagayan block: a terrestrial influx composed of quartz, micas, kaolinite, and disordered interstratified minerals, and a volcanic input, either as a dispersed contribution of coarse-grained minerals (olivine, pyroxene, plagioclase, spinel), or as a fine smectitic enrichment, a product of the degradation of ash or vitric clasts which is more difficult to detect.

The terrestrial influence increases the potassium and the aluminum content of the rocks and their fine fractions. The most evident volcanic contamination observed in the rock is the abundance of plagioclase. The calcium and sodium contents increase as potassium decreases and the $\mathrm{Ca} / \mathrm{Na}$ ratios probably reflect the basic or acid nature of the volcanic rock sources. Although the ferromagnesian minerals are common in the coarse-grained fraction, their influence on the bulk chemistry is minor. The fine-fraction of the sediments contaminated by the volcanic influx are more magnesian than the others.

The primitive signatures are modified with depth by the subsidence and the compaction that favor the chemical exchange between minerals and seawater or pore fluids. In the incipient diagenesis that affects the sediments, the influence of the heritage is still discernable. Indeed, the diagenetic mineralogical associations of the clay-size fractions depend on the lithology of the sediments.

The brown claystones are characterized by a low $\mathrm{Al}$, $\mathrm{Mg}$-Fe-rich smectite \pm clinoptilolite or phillipsite. The white interbeds associated with the brown claystones, and probably of volcanogenic origin, are characterized by an Al-rich, $\mathrm{Na}-\mathrm{Mg}$ smectite.

In the other detrital sediments, a pure smectite, if present, is masked by large amounts of disordered interstratified clay minerals. But these minerals evolve with diagenesis. In the Celebes Sea, where the terrestrial influx is more fine-grained, or more degraded before input into the basin, and where the volcanic influx is scattered throughout the sequences, the diagenetic clay association consists of a $\mathrm{Mg}-\mathrm{Ca}$ or Na smectite (or disordered interstratified clay minerals) plus a $\mathrm{K}-\mathrm{Fe}, \mathrm{Al}$ glauconite. In the Sulu and the Cagayan block sediments, where the continental influx is rich in micas, the bulk schema seems to be $\mathrm{K}-\mathrm{Fe}, \mathrm{Mg} \mathrm{ML1}=\mathrm{Na}-\mathrm{Mg}, \mathrm{Fe} \mathrm{ML} 2$ + kaolinite. 
The last transformation is mainly interpreted as a degradation of the disordered interstratified clay minerals. The magnesium and alkali contents of the pore fluids reflect the neogenesis of smectite and the degradation of the disordered interstratified clay minerals. Our data do not allow a more detailed description of the diagenesis, but they emphasize that the mineralogy and the chemistry of the bulk rock, and the initial parameters prevailing during the sedimentation control the first steps of the diagenetic evolution. Once acquired, the early diagenetic differentiations should influence subsequent transformations during thermal diagenesis, such as the illitisation of smectite.

This general interpretation does not take into account the ordered interstratified clay minerals of the volcanite Unit IV of the Sulu Basin. Local thermal processes along some fault system, or an early thermal event affecting the syn-rift deposits are apparently specific to the Sulu deposits.

\section{ACKNOWLEDGMENTS}

We are grateful to $\mathrm{Ph}$. Bertrand, who collected the samples, and to P. Tremblay who, through his careful work in Orsay, provided us with a valuable set of chemical data. We thank G. Whitney and an anonymous reviewer for helpful comments. We owe special thanks to Dr. G. Whitney for polishing the English and to the ODP staff representatives for their help and advice in the manuscript presentation.

\section{REFERENCES}

Alt, J. C., and Honnorez, J., 1984. Alteration of the upper oceanic crust, DSDP Site 417: mineralogy and chemistry. Contrib. Mineral. Petrol., 87:149-169.

Bischoff, J. L., and Rosenbauer, R. J., 1977. Recent metalliferous sediments in the North Pacific manganese area. Earth Planet. Sci. Lett., 33:379-388.

Boles, J. R., and Wise, W. S., 1978. Nature and origin of deep sea clinoptilolite. In Sand, L. B., and Mumpton, F. A. (Eds.), Natural Zeolites: Occurrence, Properties, Use: Elmsford, NY (Pergamon Press), 235-244.

Gieskes, J. M., and Lawrence, J. R., 1981. Alteration of volcanic matter in deep-sea sediments: evidence from the chemical composition of interstitial waters from deep-sea drilling cores. Geochim. Cosmochim. Acta, 45:1687-1703.

Güven, N., 1988. Smectites. In Bailey, S. W. (Ed.), Hydrous Phyllosilicates (exclusive of micas). Mineral. Soc. Am., Rev. Mineral. 19:497-560.

Hathaway, J. C., 1979. Clay minerals. In Burns, R. G. (Ed.), Marine Minerals. Short Course Notes-Mineral. Soc. Am., 6:123-148.

Hay, R. L., 1966. Zeolites and zeolitic reactions in sedimentary rocks. Spec. Pap. Geol. Soc. Am., No. 85.

Haymon, R. M., and Kastner, M., 1986. The formation of high temperature clay minerals from basalt alteration during hydrothermal discharge on the East Pacific Rise axis at $21^{\circ} \mathrm{N}$. Geochim. Cosmochim. Acta, 50:1933-1939.

Hinz, K., and Block, M., 1990. Summary of geophysical data from the Sulu and Celebes Seas. In Rangin, C., Silver, E. A., von Breymann, M. T., et al., Proc. ODP, Init. Repts., 124: College Station, TX (Ocean Drilling Program), 87-92.

Inoue, A., and Utada, M., 1983. Further investigations of a conversion series of dioctaedral mica/smectite in the Shinzan hydrothermal alteration area, northeast Japon. Clays Clay Miner., 31:401412 .

Kastner, M., and Gieskes, J. M., 1976. Interstitial water profiles and sites of diagenetic reactions, Leg 35, DSDP, Bellingshausen Abyssal Plain. Earth Planet. Sci. Lett., 33:11-20.
Kudrass, H. R., Wiedicke, M., Cepek, P., Kreuzer, H., and Müller, P., 1986. Mesozoic and Cenozoic rocks dredged from the South China Sea (Reed Bank area) and Sulu Sea and their significance for plate-tectonic reconstructions. Mar. Pet. Geol.,3:19-30.

Lawrence, J. R., Drever, J. I., Anderson, T. F., and Brueckner, H. K., 1979. Importance of alteration of volcanic material in sediments of Deep Sea Drilling Site 323: chemistry, ${ }^{18} 0 /{ }^{16} 0$ and ${ }^{87} \mathrm{Sr} /{ }^{86} \mathrm{Sr}$. Geochim. Cosmochim. Acta, 43:573-588.

Lee, Y. I., Klein, G. deV., 1986. Diagenesis of sandstones in the back-arc basins of the western Pacific Ocean. Sedimentology, 33:651-675.

Mevel, C., 1980. Mineralogy and chemistry of secondary phases in low temperature altered basalts from DSDP, Legs 51, 52 and 53. In Donnelly, T., Francheteau, J., Bryan, W., Robinson, P., Flower, M., Salisbury, M., et al., Init Repts. DSDP, 51, 52, 53: Washington (U.S. Govt. Printing Office), 1299-1312.

Murauchi, S., Ludwig, W. J., Den, N., Notta, H., Asanuma, T., Yoshii, T., Kubotera, A., and Hagiwara, K., 1973. Structure of the Sulu Sea and the Celebes Sea. J. Geophys. Res., 78:3437-3447.

Nadeau, P. H., and Reynolds, R. C., 1981. Burial and contact metamorphism in the Mancos Shale. Clays Clay Miner., 29:249_ 259

Perry, E. A., Jr., Gieskes, J. M., and Lawrence, J. R., 1975. Mg, Ca and $\mathrm{O}^{18} / \mathrm{O}^{16}$ exchange in the sediment-pore water system, Hole 149, DSDP. Geochim. Cosmochim. Acta, 40:413-423.

Rangin, C., Silver, E. A., von Breymann, M. T., et al., 1990. Proc. $O D P$, Init. Repts., 124: College Station, TX (Ocean Drilling Program).

Reynolds, R. C., and Hower, J., 1970. The nature of interlayering in mixed-layer illite-montmorillonites. Clays Clay Miner., 18:25-36.

Scheidegger, K. F., and Stakes, D. S., 1979. X-ray diffraction and chemical study of secondary minerals from Deep Sea Drilling Project Leg 51, Holes 417A and 417D. In Donnelly, T., Francheteau, J., Bryan, W., Robinson, P., Flower, M., Salisbury, M., et al., Init. Repts. DSDP, 51, 52, 53 (Pt. 2): Washington (U.S. Govt. Printing Office), 1253-1264.

Schultz, L. G., 1978. Mixed-layer clay in the Pierre Shale and equivalent rocks, northern great Plains region. Geol. Surv. Prof. Pap. U.S., 1064-A.

Sclater, J. G., Karig, D. E., Lawver, L. A., and Louden, K., 1976. Heat flow, depth, and crustal thickness of the marginal basins of the south Philippine Sea. J. Geophys. Res., 81:309-318.

Shipboard Scientific Party, 1990. Site 767. In Rangin, C., Silver, E. A., von Breymann, M. T., et al., Proc. ODP, Init. Repts., 124: College Station, TX (Ocean Drilling Program), 121-193.

Srodon, J., 1984. Mixed-layer illite-smectite in low temperature diagenesis: data from the Miocene of the Carpathian foredeep. Clay Miner., 19:205-215.

Srodon, J., and Eberl, D. D., 1984. Illite. In Bailey, S. W. (Ed.), Micas. Min. Soc. Am., Rev. Mineral., 13:495-544.

Watanabe, T., 1981. Identification of illite/montmorillonite interstratification by X-ray powder diffraction. J. Mineral. Soc. Japan, Spec. Iss., 15: 32-41 (in Japanese).

Yeh, H., and Savin, S. M., 1976. The extent of oxygen isotope exchange between clay minerals and sea water. Geochim. Cosmochim. Acta, 40:743-748.

Date of initial receipt: 2 July 1990

Date of acceptance: 27 March 1991

Ms 124B-136 